\title{
SECULARISM AND THE CONSTITUTION: CAN GOVERNMENT BE TOO SECULAR?
}

\author{
Jorge O. Elorza*
}

\begin{abstract}
When the "jurisdictions" of religion and science overlap, the conclusions they each reach sometimes conflict. For example, religiously conservative views towards sex or the formation of the universe may be undermined by the secular instruction students receive in public schools. With respect to normative matters, such as views towards sex, courts have resolved the conflicts by stating that public school teachers can neither directly contradict religious beliefs nor compel adherence to the secular view. However, with respect to empirical matters, such as how planets formed, courts have implicitly recognized - although never expressly stated - that a different standard must apply. So long as sufficient evidence exists to support an empirical claim, a public school may teach it. The fact that it directly contradicts a deeply held religious belief, as does evolution for example, is irrelevant.

How far does this principle extend? If scientific evidence leads us to conclude that a particular aspect of God cannot be true, can this be taught in the public schools? In order to explore this issue, I first lay out a framework that isolates the tension that exists between religion and science and that introduces the concept of the memist God. Second, I examine the extent to which science has spoken to the question of God's existence and I determine that it has certainly addressed one particular aspect. Specifically, science has disconfirmed the claim that the theist God has the power to violate the laws of physics. Last, once the issues are properly identified and the framework set, I explore whether teaching the non-existence of the theist God would violate

* Associate Professor of Law, Roger Williams University School of Law. B.S., University of Rhode Island; J.D., Harvard Law School. I would like to express my deep gratitude for valuable feedback to Carl Bogus, Jared Goldstein, Jon Gutoff, Diana Hassel, James Huguley, Peter Marguiles, Colleen Murphy, and David Zlotnick. Additionally, I would like to thank audience participants at the NEPOC Legal Scholarship Conference 2008 and the AALS Section on Socioeconomics 2009. I would also like to thank my diligent research assistants Lydia Dawson, Timothy Cook, Katherine Godin, and Grace Neisingh. This research was generously supported by a RWU SoL summer research grant.
\end{abstract}


the underlying values of the religion clauses. I conclude, first, that teaching that the theist God does not exist would not violate any of the underlying values and second, that the consequences of doing so are not as far-reaching as may be initially believed. 


\section{Table of Contents}

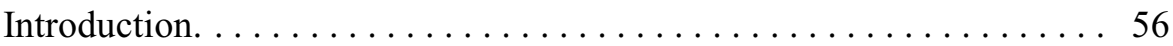

I. Religion and Secularism.................... 60

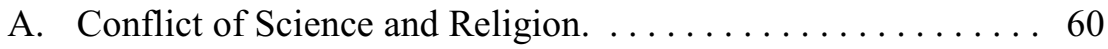

B. Can Religion and Secularism Coexist?............ 63

C. Thought Experiment. ..................... 66

II. Empiricism and the Theist God. ................. 67

A. Atheism, Deism, Theism, and Memism. ........... 67

B. Science and the Theist God.................. 73

1. Why is there something rather than nothing?. . . . . 76

2. How were galaxies, stars, planets, and other cosmic entities formed?. . . . . . . . . . . . . . . . . . . . . . 77

3. How did life on Earth begin?............... 78

4. How did humans originate? ............. 82

5. How did our moral sense originate?........... 83

6. What are consciousness and free will and how did they arise? . . . . . . . . . . . . . . . . . . . 87

7. Why do we feel religious experiences? ......... 93

C. Burden of Proof and the Evidentiary Standard. . . . . . . . 96

III. The Theist God and the Religion Clauses. . . . . . . . . . . . . 98

A. Establishment Clause Values and the Theist God.. . . . . . . 100

B. Free Exercise Clause Values and the Theist God. . . . . . . . . 105

C. Application of Framework. . . . . . . . . . . . . . . . . . 109

D. Can Government Be Too Secular?. . . . . . . . . . . . . . 112

Conclusion....................................... 114 


\section{INTRODUCTION}

In Zorach v. Clausen, Justice Douglas famously wrote that "[we] are a religious people whose institutions presuppose a Supreme Being." "This statement reflects both our history and our present. The early colonists fled the religious intolerance of Europe and settled in a new land that promised greater religious freedom. ${ }^{2}$ When the constitution was ratified, this core principle became enshrined in the first clause of the First Amendment: "Congress shall make no law respecting an establishment of religion, or prohibiting the free exercise thereof." ${ }^{3}$ Thus secured, religious freedom allowed for an open marketplace, free from government favoritism, for religions to compete with one another for adherents. ${ }^{4}$ The result has been great religious diversity and a citizenry that is unmatched, among developed nations, in its level of religiosity.

Perhaps somewhat paradoxically, the United States is also a remarkably secular nation. Because of the first amendment, its institutions and legal processes are distinctively secular and the state does not officially endorse a particular religion. ${ }^{5}$ Most notably, secularism has transformed higher education from colleges promoting Protestant values to universities promoting "objective," irreligious worldviews. ${ }^{6}$ Similarly, primary and secondary education has become a non-sectarian, secular enterprise from which religion

1. 343 U.S. 306, 313 (1952).

2. Although, the truth is that the colonists reproduced the same intolerance toward religious minorities that had earlier forced them to flee their countries. Noah Feldman argues that New England Congregationalists and Southern Baptists alike both preached the rhetoric of liberty of conscience but, in practice, the toleration of religious dissenters was at best, limited. Noah Feldman, The Intellectual Origins of the Establishment Clause, 77 N.Y.U. L. REv. 346, 379-81 (2002).

3. U.S. CONST. amend. I.

4. In Zorach, Justice Douglas writes that

[w] guarantee the freedom to worship as one chooses. We make room for as wide a variety of beliefs and creeds as the spiritual needs of man deem necessary. We sponsor an attitude on the part of government that shows no partiality to any one group and that lets each flourish according to the zeal of its adherents and the appeal of its dogma.

343 U.S. at 313. It was not actually true in the early years of the United States that there was an open marketplace of religion. In fact, many states had "established" churches. See Feldman, supra note 2, at 379-81.

5. Ahmet T. Kuru, University of Washington, Secularism in the United States, France, and Turkey: An Historical Perspective 2, Paper Presented at the annual meeting of the American Political Science Association (Sept. 1, 2005), available at http://www.allacademic.com/meta/p42250_index.html.

6. The Secular Revolution: Power, Interests and Conflict in the Secularization of American Public Life 2-3 (Christian Smith ed., 2003) (stating that college institutions that promoted a Protestant worldview were transformed into universities promoting an irreligious one). 
is "assiduously excluded." In whole, secularism has effectively monopolized the creation of new knowledge. We might therefore complement Justice Douglas's famous phrase with the following: we are also a secular people whose institutions presuppose the value of reason.

In spite of the rise of secularism, religion has not withered away; rather, both religion and secularism appear to be gaining strength. ${ }^{8}$ It may in fact be accurate to refer to the United States as both the most religious and the most secular nation in the world. ${ }^{9}$ As can be expected from such strong and opposing forces, religion and secularism have often clashed. While the conflict has taken place on a number of fronts, for purposes of the first amendment, nowhere has this clash been more intense than in the context of public education. It is within this context that I will explore the issues I raise in this article.

In recent years, notable scientists have stoked the flames of the religionsecularism dispute by publishing a spate of popular books arguing that modern science has successfully debunked the mythology of the theist God. ${ }^{10}$ Emboldened by the breadth of scientific evidence, the authors claim that the existence of the theist God is overwhelmingly unlikely to be true; so unlikely, in fact, that we can be certain in declaring that it is false. ${ }^{11}$ If they are correct in asserting that the evidence against the existence of the theist God is overwhelming, would it violate the constitution if this were taught as part of a basic science education?

Because of the growing tension between secularism and religion, and the resulting academic interest in the topic, the issues I discuss in this article are contemporary, important and real. I suspect that it is only a matter of time before the issue of the theist God's existence is raised in the courts. In fact, this issue has already begun to appear. In C.F. v. Capistrano Unified School District, a federal court was asked to determine whether a public high school

\footnotetext{
7. $I d$.

8. Id. at 7 .

9. Id. at 7 .

10. For a definition of the theist God, as opposed to the deist God, see infra text accompanying notes $49-51$.

11. The most notable proponents of this position are: Richard Dawkins, The God Delusion (2006) [hereinafter Dawkins, God Delusion]; Victor Stenger, God: The Failed Hypothesis-How Science Shows That God Does not Exist (2007); Daniel Dennett, Darwin's Dangerous Idea: Evolution and the Meanings of Life (Simon \& Schuster 1995) [hereinafter Dennett, Darwin's Dangerous Idea]; and Daniel Dennett, Breaking the Spell: Religion as a Natural Phenomenon (2006) [hereinafter Dennett, Breaking the Spell]. Sam Harris, The End of Faith: Religion, Terror, AND the Future of REAson (2004), argues from the same atheist position but emphasizes religious adherents' lack of critical reasoning regarding religious claims.
} 
teacher's statement that creationism was "superstitious nonsense" constituted a violation of the Establishment Clause. ${ }^{12}$ With the increased understanding of science and the relative ease with which a school teacher can discredit theism, ${ }^{13}$ I strongly anticipate that the tension between religion and secularism will be a fertile source of litigation in coming years.

As a preemptive response, perhaps school districts will adopt policies, much like the anti-evolution statutes of a few generations ago, ${ }^{14}$ that will explicitly prohibit teaching that the theist God does not exist. As with the teaching of evolution, the outcome should be determined by the extent to which it is a settled scientific principle. Will courts put science on trial? The court did exactly that in Kitzmiller v. Dover Area School District as it had to consider whether Intelligent Design constituted good science. ${ }^{15}$ Although the outcome was determined when a "smoking gun" proved that Intelligent Design was religious in nature, ${ }^{16}$ the trial record is replete with expert testimony on what is and is not good science. Is the scientific evidence strong enough to confidently assert that the theist God does not exist? Perhaps this question is in the Supreme Court's offing.

An even more challenging set of questions arises in the Free Exercise context. If the existence of the theist God is an empirical question, then logically, so would the question of whether the theist God commands you to have a certain belief or perform a certain act. If there is no theist God, then certainly He cannot make commands. So, if a student claims that God commands her to be pro-life, a teacher might state that as a matter of fact, it is not true. In this way, religion's normative claims may come to be directly undermined. Would this constitute the government impermissively speaking

12. 615 F. Supp. 2d 1137, 1146 (C.D. Cal. 2009).

13. At this point, I am not necessarily making the case that it is easy to discredit the philosophical or theological basis for the belief in the theist God. I am only stating that a flippant comment by a school teacher can give rise to litigation.

14. See Epperson v. Arkansas, 393 U.S. 97 (1968) (constitutional challenge to Arkansas statute that prohibited the teaching of evolution in public schools).

15. 400 F. Supp. 2d 707 (M.D. Pa. 2005).

16. The court explains that "three astonishing points emerge[d]" when the court compared early and later drafts of the textbooks in question:

(1) the definition for creation science in early drafts is identical to the definition of [Intelligent Design];

(2) cognates of the word creation (creationism and creationist), which appeared approximately 150 times were deliberately and systematically replaced with the phrase [Intelligent Design]; and

(3) the changes occurred shortly after the Supreme Court held that creation science is religious and cannot be taught in public school science classes in Edwards [v. Aguillard]. Id. at 721 . 
to the truth or falsity of religious doctrine? These, and other issues, may cause courts to consider the tantalizing question of whether there is a constitutional limit to how secular government can be.

I set out to explore this question by asking whether it would violate the First Amendment if a public institution adopted the position that the theist God does not exist. A superficial analysis of both the Establishment and Free Exercise Clauses would provoke an answer of "Yes." ${ }^{17}$ However, the answer might be different if it can be established that the existence of the theist God is not only an empirical question but also one that has already been answered by science. Would adopting this position be any different than teaching evolution or the age of the Earth in public schools?

History is littered with instances where religion and science have directly conflicted. The steady state theory, the literal reading of Genesis, and the geocentric view have all been successfully debunked by modern science. Is the theist God next? The answer will depend (1) on exactly which elements of religion are in tension with science and (2) as with all empirical claims, on the evidence available to make the case.

As such, in Part I, I discuss the tension that exists between religion, secularism, and science. I highlight the kinds of cases that have come before the courts and I explain how courts have resolved the disputes. Then, I create a thought experiment that allows me to directly address the conflict and to ground the discussion on a plausible set of facts.

In Part II, I construct an analytical framework to answer the questions raised in the thought experiment. I first identify the various kinds of Gods that may exist and I highlight the precise characteristics that distinguish the theist God from all others. I then introduce the concept of the memist God and I highlight the stakes involved in the ongoing religion-secularism debate. I then engage the literature from various scientific disciplines and reveal the extent to which religious claims have been successfully debunked by science.

In Part III, I review the values underlying the Establishment and Free Exercise Clauses and then ask whether they would be offended by teaching that the theist God does not exist. As I analyze this question, I find that none of the judges or commentators that have spoken on this issue considered the

17. See, e.g., United States v. Ballard, 322 U.S. 78, 87-88 (1944) (holding that it is "forbidden domain" for courts to speak to the truth or falsity of religious claims); Presbyterian Church v. Hull Church, 393 U.S. 440, 451 (1969) (holding that courts may not decide controversies over religious doctrine or practice); Dep't of Human Res. v. Smith, 494 U.S. 872, 877 (1990) (stating that government cannot "lend its power to one or the other side in controversies over religious authority or dogma"). See also infra notes $189-95$. 
extent to which the hard sciences addressed the question of the theist God's existence. Because of this, the constitutional issues that arise have gone virtually unnoticed.

In writing this article, my goal is to provide a framework for courts and scholars to resolve and debate the instances when religious and secular beliefs conflict. Although the stakes seem to be extraordinarily high, my conclusion is that the tension between religion and science is much overblown and exaggerated. Once the tension between them is precisely identified, we see that their level of overlap turns out to be thinner than first believed.

\section{ReLigion AND Secularism}

\section{A. Conflict of Science and Religion}

The Oxford English Dictionary defines the adjective "secular" as "of or pertaining to this world" and as a "negative term with the meaning nonecclesiastical, non-religious, or non-sacred." ${ }^{18}$ The word secular "derives from the Latin word saeculum, meaning 'this age' . . . as opposed to the eternal 'religious world."'19 However, given that religion makes a number of claims that relate to "this world" - both empirical and normative - it is impossible to precisely define secularism as that which is not religious. Contrary to what the definition of secular suggests, there is no inherent conflict between secularism and religion. Courts have recognized this point and have found that even if a government policy coincides with an explicitly religious belief, it will not be struck down on that ground. "As long as the objective can be regarded as secular, that it might also be considered religious is legally unimportant." 20

However, there are instances, on both normative and empirical grounds, where religious and secular views diverge. For example, courts have been called upon to resolve disputes where religious groups have taken offense to

18. Oxford English Dictionary (2d ed. 1989).

1) Of or pertaining to the world. 2) Belonging to the world and its affairs as distinguished from the church and religion; civil, lay, temporal. Chiefly used as a negative term, with the meaning non-ecclesiastical, non-religious, or non-sacred. 3a) Of or belonging to the present or visible world as distinguished from the eternal or spiritual world; temporal, worldly. 3b) Caring for the present world only; unspiritual.

19. Harvey Cox, The Secular City: Secularization and Urbanization in Theological Perspective 18-19 (1966).

20. Steven Smith, Separation and the "Secular": Reconstructing the Disestablishment Decision, 67 Tex. L. Rev. 955, 1004-05 (1989). 
state policies such as compulsory education laws, ${ }^{21}$ the inclusion of certain literary texts in the public school curriculum, ${ }^{22}$ the use of audio-visual equipment in the classroom, ${ }^{23}$ and the teaching of a health education course that examines family relationships. ${ }^{24}$ In each of these cases, the plaintiffs claimed that the governmental policies either undermined or contradicted one or more of their religions' normative beliefs.

Courts, however, have recognized that this does not necessarily lead to a violation of the constitution. In such a religiously diverse society, it is inevitable that religious and secular views will sometimes conflict. If the mere presence of a conflict were sufficient to find a constitutional violation, "virtually no governmental program would be constitutionally possible." 25 Therefore, to resolve these conflicts, courts required claimants to also show that either the government does not have a secular purpose or that the "principal or primary" effect is one that inhibits religion. ${ }^{26}$ In terms of what constitutes an impermissible effect, courts have stated that government may not directly contradict religious beliefs ${ }^{27}$ and that it cannot compel adherents to adopt a secular, orthodox belief. ${ }^{28}$

21. Wisconsin v. Yoder, 406 U.S. 205 (1972) (Amish parents convicted of violating state's compulsory education laws).

22. Grove v. Mead School District, 753 F.2d 1528 (9th Cir. 1985) (parents objected to the use of book, The Learning Tree, because it allegedly promoted secular values).

23. Davis v. Page, 385 F. Supp. 395 (D.N.H. 1974) (parent objected to a number of school policies that conflicted with religious beliefs).

24. Id.

25. Grove, 753 F.2d at 1542 ; see also id. at $1542-43$ :

Authorities list 256 separate and substantial religious bodies to exist in the ... United States.... If we are to eliminate everything that is objectionable to any of these warring sects or inconsistent with any of their doctrines, we will leave public education in shreds. Nothing but educational confusion and a discrediting of the public school system can result. . . .

Citing McCollum v. Bd. of Educ., 333 U.S. 203, 235 (1948).

26. Lemon v. Kurtzman, 403 U.S. 602, 612-13 (1971).

27. Kent Greenawalt, Secularism, Religion, and Liberal Democracy in the United States, 30 CARDozo L. Rev. 2383, 2388 (2009):

In teaching that the Earth is not the center of the universe and that discrimination by gender and race is unjust, a school will run afoul of the opinions of some religions. This conflict is unavoidable. What the school cannot do is directly to teach the truth or falsity of the religious ideas themselves. (emphasis added).

28. The Court draws a distinction between merely exposing students to views that conflict with their religious views and actively compelling students to adopt alternative views. See Engel v. Vitale, 370 U.S. 421, 431 (1962) (striking down policy of use of official school prayer in public school in part because of its "indirect coercive pressure"); School Dist. of Abington Twp., Pa. v. Schempp, 374 U.S. 203, 223 (1963) (striking down policy of reading from the Bible in public schools and holding that "it is necessary in a free exercise case for one to show the coercive effect of the enactment as it operates against him in the practice 
While these approaches have proved workable for resolving disputes over normative matters, they are unhelpful for resolving empirical matters. Therefore, when religious beliefs based on empirical claims conflict with good science, courts must use a different standard. For example, suppose that a public high school science teacher includes the following question on an exam: what is the age of the Earth? If a student, motivated by her religious beliefs, writes " 6,000 years" as the answer and is given a lower grade because of it, has the school or the teacher violated the First Amendment? ${ }^{29}$

First, it seems clear that the government is directly contradicting a religious belief. Second, at the risk of receiving a lower grade, the government is also compelling a student to adopt the secular belief. Although the standard for resolving conflicts on normative matters is being violated; it is inconceivable that any court would find that the school had violated either of the religion clauses. Schools must have the ability to teach settled and uncontroversial scientific facts regardless of whether they might offend some quirky or idiosyncratic religious beliefs. ${ }^{30}$ Whenever governmental policies contradict religious beliefs on an empirical matter, the standard must be: whether the government has sufficient evidence to substantiate its claim. ${ }^{31}$ Without sufficient evidence it is unclear that there can be a valid secular purpose, and it is unlikely that the principal and primary effect would be anything other than the inhibition of religion.

It is only with respect to empirical claims that science offers any insight. As such, the conflict between religion and science exists only when conclusions on empirical claims diverge. For the remainder of this article, I will explore only the religious and secular conflicts which are based on empirical matters. ${ }^{32}$

of his religion").

29. Perhaps the teacher is aware that the student's answer is religiously motivated or perhaps the teacher is not. I do not believe this distinction would influence the constitutional resolution of this case one way or the other.

30. See Crowley v. Smithsonian Inst., 636 F.2d 738 (D.C. Cir. 1980) (holding inter alia, that Smithsonian Museum's exhibition on evolution did not considerate an impermissible establishment of religion).

31. Cf. Epperson v. Arkansas, 393 U.S. 97 (1968). Although the teaching of evolution in Epperson conflicted with deeply held religious beliefs, the Court assumed, without question, that evolution was an appropriate subject for study. At the time of the decision, only two states, Arkansas and Mississippi, had anti-evolution statutes on their books. In effect, the Court determines that since evolution had become the orthodox view supported by evidence and good science, it could and should form part of a general public education.

32. There are normative claims, that follow logically from an empirical claim, that are nonetheless implicated. For example, if the theist God does not exist, then it is certain that the theist God cannot make 


\section{B. Can Religion and Secularism Coexist?}

The Court in School District of Abington Township, Pennsylvania $v$. Schempp states - and lower courts have consistently affirmed-that government "may not establish a 'religion of secularism' in the sense of affirmatively opposing or showing hostility to religion." ${ }^{33}$ This rule however, is seemingly undermined by a proposition adopted by a number of lower courts that government can contradict or oppose religious beliefs when there exists a valid secular purpose for doing so. ${ }^{34}$ Taken together, these statements may erroneously lead one to conclude that government may establish the religion of secularism whenever there is a valid secular purpose.

However, courts have clarified that when they speak of the "religion of secularism," they refer only to organized groups of secular humanists and not to the principles of secularism..$^{35}$ Thus, the law would allow for the teaching of secular principles but not for a particular religious group to be favored over another. The fact that secular principles happen to coincide with those of a religious group would not render government action unconstitutional. ${ }^{36}$ Therefore, if a public school taught that the Earth is older than 6,000 years, it would not be substituting the beliefs of one religion-secular humanism - over the beliefs of another. Instead, it would merely be promoting the principles of secularism over religious doctrine. Although they clearly

moral commands. See infra Part III.B.

33. Abington v. Schempp, 374 U.S. 203, 225 (1963).

34. Harper v. Poway Unified Sch. Dist. 445 F.3d 1166, 1190 (9th Cir. 2006), vacated as moot Harper ex rel. Harper v. Poway Unified School Dist., 549 U.S. 1262 (2007)

Public schools are not limited to teaching materials that are consistent with all aspects of the views of all religions. So long as the subject and materials are appropriate from an educational standpoint and the purpose of the instruction is secular, the school's teaching is not subject to a constitutional objection that it conflicts with a view held by members of a particular religion. Accord Grove v. Mead School District, 753 F.2d 1528, 1542 (9th Cir. 1985) ("Were the free exercise clause violated whenever governmental activity is offensive to or at variance with sincerely held religious precepts, virtually no governmental program would be constitutionally possible.”); Mozert v. Hawkings County Bd. of Educ., 827 F.2d 1058, 1068 (6th Cir. 1987) ("The lesson is clear: governmental actions that merely offend or cast doubt on religious beliefs do not on that account violate free exercise. An actual burden on the profession or exercise of religion is required."), quoting Grove, 753 F.2d at 1543.

35. See Grove, 753 F.2d at 1537; Malnak v. Yogi, 592 F.2d 197, 207 (3d Cir. 1979) (Adams, J., concurring).

36. See Van Order v. Perry, 545 U.S. 677, 690 (2005) ("Simply having religious content or promoting a message consistent with a religious doctrine does not run afoul of the Establishment Clause."); McGowan v. Maryland, 366 U.S. 420, 442 (1961); Harris v. McRae, 448 U.S. 297 (1980) (stating that government advocacy to limit Medicaid funding for abortions does not violate the establishment clause merely because it incorporates into law the teachings of the Catholic Church). 
contradict each other, the government would still be able to teach the secular view.

The court in Crowley v. Smithsonian Institution discussed the balance between an individual's freedom of religious belief and the public's right to receive knowledge disseminated by the government in public schools. ${ }^{37}$ In the context of the teaching of evolution, the court states that the "balance was long ago struck in favor of diffusion of knowledge based on responsible scientific foundations, and against special constitutional protection of religious believers from the competition generated by such knowledge diffusion. ${ }^{38}$ We may infer that if good science directly conflicts with an empirical religious belief, the constitution commands that the religious belief must yield.

The balance which the Crowley court discusses however, was struck under an assumption that I believe can no longer be sustained. Specifically, it was believed that the theory of evolution does not provide a set of comprehensive answers to life's most profound questions in the same way that religion does. ${ }^{39}$ For instance, in Malnak v. Yogi, Judge Adams' well-regarded and thoughtful opinion stated that evolution is an "isolated theor[y]" that does not "proffer a systematic series of answers" to individuals' ultimate concerns. $^{40} \mathrm{He}$ goes on to cite St. Thomas Aquinas to argue that religion - "theology," to be more exact — is the "ruling science" to which all other sciences are subordinate. ${ }^{41}$ It is only when the subordinate, isolated "sciences" are combined into a comprehensive belief system that the "ruling science" of religion emerges. Judge Adams concluded that "[i]t is just such a 'ruling science' that the establishment clause guards against."

Given the state of our scientific understanding of the natural world, I argue that the theory of evolution has in fact become the "ruling science" to which Judge Adams alludes. In the opening paragraph of his classic book, The Selfish Gene, Richard Dawkins includes the following passage:

We no longer have to resort to superstition when faced with the deep problems: Is there a meaning to life? What are we for? What is man? After posing the last of these questions, the eminent zoologist G.G. Simpson put it thus: "The point I want to make

37. Crowley v. Smithsonian Inst., 636 F.2d 738, 744 (D.C. Cir. 1980).

38. Id. (emphasis added).

39. See Malnak v. Yogi, 592 F.2d 197, 209 (3d Cir. 1979) (Adams, J., concurring).

40. $I d$.

41. $I d$.

42. $I d$. 
now is that all attempts to answer that question before 1859 are worthless and that we will be better off if we ignored them completely." 43

The point he is making is that before the publication of Charles Darwin's On The Origin of Species in 1859, we were flying blind when trying to answer these questions. The theory of evolution and its full implication sheds light on some of the most mundane, as well as the most profound, questions humans can ask themselves. Without the benefit of an evolutionary perspective, ancient philosophers, theologians, scientist, and all other thinkers were at a distinct disadvantage.

I believe it is fair to state that most people simply do not understand the full implication of evolutionary theory. Evolution is not confined to explaining how apes became man or even to explaining all of the biological diversity that exists on Earth; evolution goes much farther. The relatively new concept of "Universal Darwinism" is being employed to understand how evolution functions in other spheres. ${ }^{44}$ Darwinian principles are being applied to understand how culture evolves and this is shedding light on the evolution of languages, music, laws, and mores. ${ }^{45}$ Darwinism is being used to explain the growth and spread of computer viruses on the internet. ${ }^{46}$ It is also being used to understand fundamental physics and the possible existence of other universes ${ }^{47}$ Even Darwin himself was unaware of the grandiosity of the theory of evolution.

As Darwinism is being used to answer these small and large questions, it is becoming progressively more difficult to maintain Justice Adams' suggestion that evolution is not a direct rival of religion. To be more precise,

43. Richard Dawkins, The Selfish Gene 1 (Oxford Univ. Press 1977) (1976) [hereinafter, Dawkins, The Selfish Gene].

44. The phrase "Universal Darwinism" may have been coined by Richard Dawkins, see RiCHARD Dawkins, Universal Dar winism in Evolution from Molecules to Man (D.S. Bendall ed., Cambridge Univ. Press 1983) [hereinafter DA WKINS, UNIVERSAL DAR WINISM], but the concept has also been developed elsewhere. See also Dennett, Darwin's Dangerous Idea, supra note 11; Susan Blackmore, The Meme Machine (Oxford Univ. Press 2000); Lee Smolin, The Life of the Cosmos (Oxford Univ. Press 1997).

45. See Richard Brodie, Virus of the Mind: The New Science of the Meme (Integral Press 1996); but see Darwinizing Culture: The Status of Memetics as a Science (Robert Aunger ed., Oxford Univ. Press 2000) (thoroughly examining and criticizing the fledgling science of memetics from various perspectives) [hereinafter DARWINIZING CULTURE].

46. Dennett, Breaking the Spell, supra note 11, app. A, at 343-47.

47. See, e.g., SMOLIN, supra note 44, at 92-93 (arguing that universes, with physical laws that allow for black holes, reproduce other universes); Alejandro Jenkins \& Gilad Perez, Life in the Multiverse, ScI. AM., Jan. 2010, at 42 (hypothesizing that multiple universes, each with their own laws of physics, may have been created out of the same process that gave rise to our own universe). 
it is not religion itself that is undermined by evolution; it is a subset of religion, namely, a particular view of God that is called into question. We should therefore adjust our language to reflect the fact that the tension does not necessarily lie between science and religion but instead between science and a particular view of God.

\section{Thought Experiment}

Can the principle from Abington and Crowley be carried to its logical conclusion? Is it true that government can contradict any religious belief so long as it is based on "responsible scientific foundations"? ${ }^{48}$ If the weight of sound scientific evidence leads us to conclude that the theist God does not exist, would teaching so in the public schools violate the values underlying the religion clauses?

To answer these questions, I set up the following thought experiment. Suppose that a small college town adopted a series of textbooks for its high school science curriculum that proactively sought to debunk the existence of the theist God. Perhaps, after much deliberation, the school board adopts a textbook series that contains the following statement in each book's preface: "There are no supernatural agents interacting in the natural world. For purposes of this textbook, the 'natural world' consists of and entails everything from moments after the Big Bang to the present day. It specifically does not include anything occurring before the Big Bang." ${ }^{49}$

Perhaps the hypothetical textbooks also include a number of insets that discuss empirical claims made by religious and non-religious groups that have since been debunked. For example, in conjunction with the standard scientific curriculum, the insets might discuss such matters as astrology, alchemy, Lysenko's biology, the steady state theory, the geocentric theory, and Intelligent Design to name a few. Pedagogically, the insets may be defended on the grounds that they demonstrate the historical hazards of basing empirical claims on non-scientific grounds and of emphasizing the superiority of good science on all empirical matters.

If the adoption of these textbooks were challenged on either Establishment or Free Exercise grounds, would it be upheld by the Court?

48. Crowley, 636 F.2d at 744.

49. Of course, since Newtonian science breaks down below the so-called Planck length, it would be more accurate to assert that the statement does not refer to anything before a micro-second after the Big Bang. Since this represents a change of infinitesimal proportions, I decided to refer simply to the time before the Big Bang. The analysis that follows is not in any way affected by this change. 


\section{EMPIRICISM AND THE Theist GoD}

\section{A. Atheism, Deism, Theism, and Memism}

Before considering the constitutional implications of adopting this series of textbooks, it is important to specify precisely what is at stake. Although the textbooks would exclude a certain aspect of the theist God, other views of God would remain undisturbed.

There are four views of God that cover the entire spectrum: the theist, deist, atheist, and what I call the memist view. ${ }^{50}$ The theist view ascribes the broadest powers to God. The theist believes that God is not only the spark that gave birth to the universe but that He has also intervened in the natural world and has violated the laws of physics since the point of creation. This view encompasses the full range of beliefs spanning from an all-knowing, allpowerful God to the more limited God who intervenes periodically, provides wise counsel, comforts His followers, issues commands, or in any way interacts in the natural world. The theist God may take an interest in human affairs. He may answer prayers, perform miracles, help people find lost items, or perform any range of activities that cause Him to intervene in the natural world. This category is broad enough to encompass the views shared by the three great religions of Judaism, Christianity, and Islam as well as the views of countless other religions which believe that God acts independent of human action.

Opposing the theist view, the deist believes that God is the initial spark that gave birth to the universe but His influence on worldly affairs ended there. To the deist, God sits back and lets the process He set in motion play itself out. The deist God does not perform miracles, does not interact with His believers, and does not intervene in the natural world. The atheist God, of course, does not exist. ${ }^{51}$

From the perspective of science, the deist and atheist views are identical. From the moment of the Big Bang to the present time, deists and atheists can

50. For purposes of this article, the pantheist God will be identical to the deist God. Dawkins writes that, "[p]antheists don't believe in a supernatural God at all, but use the word God as a non-supernatural synonym for Nature, or for the Universe, or for the lawfulness that governs its workings." The pantheist God is a "metaphoric or poetic synonym for the laws of the universe. Pantheism is sexed-up atheism." DAWKINS, God Delusion, supra note 11, at 18 (although Dawkins describes a difference between pantheism and deism, that distinction is irrelevant for the argument in this article).

51. Dawkins, God Delusion, supra note 11, at 18. 
agree on every particular about the universe. ${ }^{52}$ The only disagreement lies in what each group believes occurred before that critical first moment. ${ }^{53}$ While deists believe the universe was the work of an intelligent creator, atheists believe that there is no evidence to believe in such a being. ${ }^{54}$ Since both sides must readily admit that there is no evidence for the others' views, each must concede that the opposing view has an equal chance of being correct. Therefore, the disagreement between deists and atheists is of no consequence. All that matters is that both sides agree that God has not intervened since the initial moment in such a way that would violate the laws of physics. Science concerns itself only with such matters as may be confirmed or disconfirmed. The fact that evidence predating the Big Bang is inaccessible to us leaves science incapable of resolving the differences between atheists and deists.

Lumping atheism and deism together allows us to avoid the truly confounding philosophical question of " $[\mathrm{w}]$ hy is there something rather than nothing?" 55 The issue of the ultimate beginning is irrelevant here because both atheists' and deists' beliefs lack all evidence. ${ }^{56}$ What is fully relevant however, is the question of what has occurred since the initial spark. Has a supernatural agent intervened since the beginning or has it not? This is where theists' beliefs diverge in a meaningful way from those of atheists and deists. Therefore, the question of whether a theist God exists, as distinct from the deist God, focuses exclusively on the time period between the Big Bang and

52. Atheists and Deists can agree on all aspects of the natural world but of course, they very likely will disagree on the particulars. What is important, however, is that there is no inherent conflict between their views in the same way that there is between Atheism/Deism and Theism.

53. In fact, even among non-deist scientists, there is a great deal of disagreement as to what occurred before the Big Bang. See, e.g., Paul Steinhardt \& Neil Turok, The Endless Universe: Beyond the BIG BANG 61-65 (Doubleday 2007) (describing the "cyclic universe" theory as one where the Big Bang gives way to the Big Crunch, causing immense energy to build up to the point where there is once again a Big Bang); SMOLIN, supra note 44, at 92-93 (describing the "fecund universes" theory and arguing that the collapse of black holes causes a Big Bang and the creation of another universe).

54. Dawkins, God Delusion, supra note 11, at 18.

55. This question was famously posed by the German philosopher Leibniz. See GotTFRIED Wilhelm Leibniz, The Ultimate Origin of Things (1697).

56. It is possible that some people might claim direct experiential evidence to support their views. However, by this statement, I merely mean that each side lacks the kind of evidence that would speak to the empirical truth or falsity of the underlying claim. Since empirical evidence from a time before the big bang is inaccessible to us, the evidence does not speak to the presence, or lack thereof, of a deist God. 
the present. ${ }^{57}$ This makes it an entirely empirical question, and one to which science has a great deal to contribute.

There exists ample evidence upon which to base our beliefs about the course of the universe from the Big Bang to the present. By limiting the inquiry to this time period, we are able to avoid the unmanageable question of what occurred before then. In other words, we can focus on answering the purely epistemological question-i.e., what we know-and avoid the ontological one-i.e. what is. If we compare the scientific evidence to the theist and atheist/deist views, we should be able to determine which one more accurately reflects the world in which we live. As in all empirical matters, the more accurate model should be accepted.

The last view of God is what I refer to as the memist view. ${ }^{58}$ Based on the concept of the meme, ${ }^{59}$ the memist God resides entirely in the minds of its adherents. Although he does not use the terminology of memes, perhaps the clearest articulation of the memist view comes from William James' timeless book, The Varieties of Religious Experience. James states that the divine is "the feelings, acts, and experiences of individual men in their solitude, so far as they apprehend themselves to stand in relation to whatever they may consider the divine. ${ }^{60}$ As for the belief in supernatural agents, James writes

57. This is not entirely accurate. Various modern theories posit that there was, in fact, existence before the Big Bang. The multiverse theory postulates that our universe was born of a black hole within another universe. See SMolin, supra note 44. The cyclic universe theory postulates that our universe goes through an endless cycle of Big Bang and big crunch. See Steinhardt \& Turok, supra note 53. For purposes of this article, however, we can treat this statement as true because we are only concerned with what occurred from the Big Bang to the present. If physicists find a way to access information before the Big Bang, then that information will also be empirical. Its only effect, for purposes of this article, would be to push the initial date of inquiry from the Big Bang to some earlier point.

58. I refer to this view of God as "memist" mainly for two reasons. First, it is a God that emerges through a memetic perspective. As such, "memist" emerges from the root word "meme." Second, I hoped to use the word "meist" instead of "memist" because phonetically it more closely fits with theism and deism. However, I was disappointed to find that Meism has already been taken. Apparently, it has been used to represent something akin to Egoism.

59. A meme is a unit of cultural information in the same way that a gene is a unit of genetic information. The great philosophical insight of memetics is that evolution is "substrate neutral," meaning that it is not limited to biological information-i.e., genes. So long as information has variation, selection, and heredity, the evolutionary process will run its course. Thus, information stored in the brain as well as information stored on computers can and does undergo evolution.

Through the process of Darwinian evolution, memes mix, blend, and re-combine with other memes to grow in complexity. The most successful memes are simply the ones that are able to make the most copies of themselves. See Dawkins, The Selfish Gene, supra note 43; Blackmore, supra note 44; and Dennett, Breaking the Spell, supra note 11, app. A.

60. William James, Varieties of Religious Experience 36 (The Modern Library 1994) (1936). James uses the definition to refer to "religion" and not to the "divine." However, this definition accurately 
that " $[t]$ he more concrete objects of most men's religion, the deities whom they worship, are known to them only in idea." ${ }^{\prime 61}$ But being "mere" ideas in no way lessens their significance in the lives and minds of adherents. In fact, they are as real as any other perception by the senses. ${ }^{62}$

The memist God is virtually identical to the theist God. "He" lays down a moral code by which adherents must live and provides an avenue by which believers may answer the transcendental, ultimate questions that lie at the heart of religion. The one distinction between the memist and the theist God is that the memist God does not violate the laws of physics. In every other respect, the memist and theist God are identical.

In effect, the memist God is merely the theist God without the power to violate the laws of physics. The memist God may be thought of as a mere placeholder used to distinguish the one attribute of the theist God to which science speaks. I choose, however, to give this idea it's own name because: (1) giving it a proper name makes it easier to refer to and (2) it has origins that are worth exploring independent of the goal of distinguishing it from the theist God. For example, as counterintuitive as it might sound, the memist God is the only God that has direct evidence supporting its existence. While the existence of both the deist and theist God can be called into question, the memist God most certainly exists! ${ }^{63}$ For example, you might ask: does honor or justice exist? Certainly, they motivate individuals to action and their actions have a tangible effect on the natural world. It should also be undisputed that even though we have scant knowledge of exactly how the brain stores memories, ${ }^{64}$ concepts such as honor and justice exist within people's minds. ${ }^{65}$ Whatever minimal requirements must be met for something to "exist," honor and justice

captures James' and my topic. James goes on to distinguish the "divine" from the more flippant or lighthearted of man's "reactions upon life," however total they may be. Id. at 40 . To James, in order for beliefs to be considered religious, they must always signify a solemn, grave and serious state of mind. Id. at 43-45. In addition, religion does not concern itself with matters to which people stoically resign themselves out of necessity, but instead they effortlessly do so with passionate happiness. Id. at 48-60.

61. Id. at 62 (emphasis added).

62. Id. at 65 (“. ... we turn towards them and from them, we seek them, hold them, hate them, bless them, just as if they were so many concrete beings. And beings they are, beings as real in the realm which they inhabit as the changing things of sense are in the realm of space.").

63. Dawkins, Universal Darwinism, supra note 44, at 193 ("God exists, if only in the form of a meme with high survival value ... in the environment provided by culture.").

64. See generally Joe Z. Tsien, The Memory Code, SCI. AM., July 2007, at 52 (containing an excellent account of recent research on the storage of memories in the brain).

65. See generally DAR WINIZING CULTURE, supra note 45 (critically examining the concept of the meme). 
surely meet them. Similarly, the memist God is as real as any other concept that exists in the brain.

Although the memist God performs all His work in a person's brain, $\mathrm{He}$ may nonetheless command His adherents to obey a moral code. For example, if a person believes that the memist God wants her to show kindness towards others, then her having such a belief, in and of itself, makes it true. If the God that I have in my mind wants me to donate to the needy, then it is objectively true that God - the one I have in my head - wants me to do it.

In another example, a person might believe that the memist God has helped children escape from a burning house. In order for this belief to be empirically true, God would have to act within a person's brain. For example, it may be true that the concept of God that another person holds in their mind inspired them to rescue the children. It might also be true that somehow the children's own belief in God gave them the strength to decide that they needed to take action. In each of these cases, it would be accurate to conclude that God helped them escape. This is the memist God. ${ }^{66}$

66. The memist God is born out of an evolutionary perspective. In particular, it relies on the concept of a "meme," which itself is a result of applying evolutionary theory to the study of culture. To understand memes, it is first important to understand genetic evolution and the concept of a gene. It is undisputed that humans share many genes in common and that no two humans share any molecules of matter in common. The matter that comprises my body is different from that which comprises other people's bodies. It is only the genetic information that we share.

Evolutionary theory tells us that the process of evolution will occur so long as three elements are present: variety, selection/competition, and heredity. With different kinds of information existing, evolution may then "select" for the information that is best at surviving and replicating. When the information is able to make copies of itself, within this environment of variety and competition, evolution will run its course and create information that is progressively better at surviving and replicating. This is the standard evolutionary process that has allowed information encoded in DNA to create all of the biological diversity that exists on Earth. Blackmore, supra note 44, at 10-11.

The revolutionary insight of memetics, however, is that this evolutionary process is not limited to genetic information but is instead "substrate neutral." In other words, evolution can run its course with any kind of information that shares the same three elements of variety, selection/competition, and heredity. Of course, the human body stores information in more than just genetic material; it also stores information in the brain. Just as a unit of genetic information is called a gene, a unit of cultural information is called a meme. A meme is therefore defined as information such as an idea, a tune, a ritual, a symbol, or anything that can be copied by imitation. There are certainly a variety of ideas that exist and some of them are better than others at being stored in human minds. Thus, there is variety and selection. It is also clear that ideas make copies of themselves so that new ideas are spawned. All of the required elements for evolution are present; memetic information should evolve just as genetic information does. See generally BLACKMORE, supra note 44; Dawkins, The Selfish Gene, supra note 43; Dennett, Breaking the Spell, supra note 11.

In fact, there is substantial evidence to suggest that memetic information evolves. It has long been understood that languages, music, morals, symbols, rituals, and entire cultures evolve. Memetics, therefore, predicts (maybe it postdicts) that our ideas of God have also evolved over time. See generally BLACKMORE, 
Alternatively, it might be believed that God violated the laws of physics and intervened to rescue the children. Perhaps it is believed that God provided a protective shield around the children so that as the house burned, the children would be safely sheltered inside. Since this would require divine intervention, independent of human action, the memist God could not perform such a function. Since such intervention would violate the laws of physics, the theist God would be required.

The following graphic breaks down the various views of God and identifies - in the shaded region - the particular aspect of the theist God that is called into question by science. It is this view of God-and only this view - that the hypothetical textbooks are designed to address. From this point forward, whenever I refer to the theist God, I refer only to the theist God as distinguished from the deist God and memist God. At times, I will refer to the specific attribute-i.e. the ability to violate the laws of physics - that distinguishes Him from the other kinds of Gods, but I will do so only to emphasize a point. For the remainder of this article, when I refer to the theist God, I mean only the shaded region below:

\section{Initial Spark Violates the Laws of Prescribes a Moral} Physics

\section{Code}

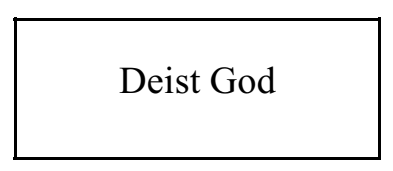

Memist God (or the theist God without the power to violate the laws of physics)

\begin{tabular}{|lll|}
\hline Theist God & Theist God & Theist God \\
\hline
\end{tabular}

supra note 44; Dawkins, The Selfish Gene, supra note 43; Dennett, Breaking the Spell, supra note 11.

While the memist God would have all of the powers to prescribe a moral code as would the theist God, religious groups might object to the memist God on the grounds that it does not have a divine source. Since it is contained entirely in the human mind, it may be believed that its stature is comparatively diminished in relation to either the deist or theist God. However, I argue that even though it does not have a divine origin, religious adherents should take solace in the fact that this should not diminish its level of constitutional protection. 


\section{B. Science and the Theist God}

The statement in the hypothetical textbooks addresses itself exclusively to the theist God that violates the laws of physics. Our inquiry is therefore limited only to this view of God as distinguished from all others. In this section, I argue that the disconfirmation of the theist God is not only hypothetically possible, but that it has already been achieved. This relates directly to the constitutional question for two separate reasons. First, if science has in fact done so, then it speaks to whether a local school board would have a valid secular purpose for adopting a set of textbooks that teach it. And second, if people are convinced that science has disconfirmed the theist God, then it makes it ever more likely that someone, namely a teacher, will address the matter in the classroom.

Since science and the theist God both make representations of the natural world, we are able to test which theory is more accurate. This is possible because a world with a theist God is fundamentally different than a world without one. ${ }^{67}$ In particular, a world without a theist God is one where natural phenomena may be understood as a gradual process over time. However, a world with a theist God that violates the laws of physics produces a world with "ontological discontinuities." ${ }^{98}$ In other words, evolution provides a smooth transition from point to point; whereas, the world with the theist God is one with discontinuities that cannot be understood without resorting to the divine. Since each theory predicts a different world, we can compare them to our observations of the universe to determine which one more accurately reflects the world in which we live. As with all empirical theories, the one which most accurately reflects our observations should be accepted. The less accurate one may be discarded.

There is great disagreement within the scientific community on the particulars of the long cosmological, chemical, and biological processes that led to the appearance of humans on Earth. For instance, astrophysicists debate whether the young universe experienced rapid inflation moments after the Big

67. Dawkins makes a similar point. He states that a God that intervenes in the natural world would leave behind traces that could be empirically tested. See Dawkins, God Delusion, supra note 11, at 58-59. See also STENGER, supra note 11, at 70-71.

68. See Pope John Paul II, Message to the Pontifical Academy of Sciences: On Evolution, § 6 (Oct. 22, 1996); see also Kitzmiller v. Dover, 400 F. Supp. 2d 707, 736 (M.D. Pa. 2005) (“[Intelligent Design] posits that animals did not evolve naturally through evolutionary means but were created abruptly by a non-natural, or supernatural, designer.") (emphasis added). 
Bang; cosmologists debate the nature, extent, and effect of dark matter on the rotation of galaxies; geologists and chemists debate the precise combination of elements which existed on a young Earth; biologists debate the process that gave rise to DNA; and so on. What is clear however, is twofold. First, scientists have developed remarkably accurate models to understand the natural world and to predict the future. These models, such as whether the Earth revolves around the Sun, have been repeatedly scrutinized and consistently verified so that we may feel comfortable in declaring that they are accurate and therefore, correct. Second, there is virtual unanimity that an evolutionary process of descent with modification is the mechanism that explains the wide range of genetic diversity that exists on Earth. Can science and evolution also explain the long history of the universe that has brought us from the Big Bang to the present day? If so, can it do so with sufficient accuracy so that we may declare with certainty that it is the product of a gradual process without the need of a theist God? I will argue that both of these questions can be answered in the affirmative.

Using research from the hard sciences, I argue that there are only six "mysteries"-numbered 2-7 below-that must be answered in order to eliminate the "ontological discontinuities" that give rise to religious groups' invocation of the theist God as an explanation for natural phenomena. If science can provide a gradual process to answer the following questions, then the theist God need not be invoked:

1. Why is there something rather than nothing? ${ }^{69}$

2. How were galaxies, stars, planets, and other cosmic entities formed?

3. How did life on Earth begin?

4. How did humans originate?

5. How did our moral sense originate?

6. What are consciousness and free will and how did they arise?

7. Why do we feel religious experiences?

If the world can be understood entirely through natural means, then there is no need to resort to supernatural explanations (to explain the natural world). Since the question of the theist God's existence is an entirely empirical one, if we are able to provide a gradual process to answer the questions above, the theist God disappears.

Theist apologists have often sought to find gaps (or ontological discontinuities) in our understanding of the natural world in order to argue that

69. For purposes of this article only, this is identical to the question: What is the origin of the universe? See supra text accompanying notes $52-56$. 
God exists. ${ }^{70}$ According to their arguments, since empirical methods cannot fill in all of the blanks, God is the only possible explanation. ${ }^{71}$ This is not to suggest that science has in fact filled in all of the gaps. On the contrary, I strongly believe that gaps will always exist. ${ }^{72}$ I do not, therefore, set out to prove the un-provable. What I do set out to show, however, is that the "God of the Gaps" argument is illogical and seriously flawed.

Science has provided explanations for a wide range of phenomena that were once thought to be beyond our ability to comprehend. In doing so, it has significantly narrowed the gaps in our understanding of the natural world. However, both Heisenberg's Uncertainty Principle and String Theory tell us that we will never reveal all of the mysteries in the natural world, particularly those that lie at the quantum level. ${ }^{73}$ Unfortunately for religious groups, this does not help their cause. If we were to seriously employ the "God of the Gaps" argument, the God that would emerge is fundamentally different from the theist God. This God would look more like the fundamental forces of nature, such as the electromagnetic, weak, strong, or gravitational forces. I will return to this argument at other points in this section.

Also, it is often argued that science can only provide, at best, a natural account of the natural world. Even if science's account is complete, it is still not an argument against God. It might be argued that God is something altogether different that cannot be perceived or perhaps even understood. Thus, the empirical evidence does not speak, one way or the other, to the question of God's existence.

This argument is wrong for two reasons. First, while this argument may be valid to support the possible existence of a deist God, it is entirely unhelpful regarding the theist God. Since the existence of a theist God is an empirical question, empirical evidence would, of course, speak directly to that question. Second, even if it is suggested that the theist God may not be perceptible to us-perhaps because He prefers that we not be aware of His

70. See, e.g., Stenger, supra note 11, at 13-14; Dawkins, God Delusion, supra note 11, at $125-34$ (stating that it is "utterly illogical" to demand a complete narrative without any gaps. It is akin to demanding a "complete cinematic record" of a murderer's every step before convicting him of a crime.).

71. See Stenger, supra note 11, at 13-14; Dawkins, God Delusion, supra note 11, at 125-34.

72. Brian Greene, The Elegant Universe: Superstrings, Hidden Dimensions, and the Quest for the Ultimate Theory 156 (W.W. Norton \& Co. 1999) (stating that the Heisenberg Principle tells us that at the quantum level, we can never know the precise position and velocity of any object. As Brian Greene describes, "in string theory there is no way to expose the sub-Planck-scale 'imperfections' in the fabric of space. In a universe governed by the laws of string theory, the conventional notion that we can always dissect nature on ever smaller distances, without limit, is not true.").

73. Id. 
existence - this argument is still unhelpful. ${ }^{74}$ Religious groups should be very careful not to define the theist God as that which we cannot see, hear, feel, or otherwise perceive. Otherwise, it would be altogether unclear why anyone would feel the need to invoke the theist God to explain any natural phenomena. ${ }^{75}$ Similarly, it must be conceded that one can never disprove the non-existence of anything. Just as it may be impossible for someone to altogether disprove the theist God's existence, it is impossible for anyone to disprove that an insubstantial pink elephant, for instance, is sitting next us at this moment. The non-disprovability argument is, frankly, not a good one. ${ }^{76}$

Last, neither the "God of the Gaps" nor the non-disprovability arguments are helpful in building the case for the theist God's existence. Both of these are negative arguments against the limits of empirical science and not positive arguments for the existence of the theist God. As such, even if they insightfully critiqued empirical science, they do not provide one iota of positive evidence in favor of what they set out to prove. As a response, in the following sections, I will provide positive evidence for a narrative of the natural world that proceeds as a gradual process and does not include supernatural explanations.

\section{Why is there something rather than nothing?}

Humans might never have an answer to this question. Our inability to answer it is what may continue to provide the strongest fuel to the voices of the religiously inclined. However, this is entirely immaterial to the argument I develop in this article. As I have mentioned, our inquiry is limited only to what has occurred from the moment of the Big Bang to the present. ${ }^{77}$ What occurred before that point does not relate to the existence of the theist God, as opposed to the deist God.

\footnotetext{
74. This argument is unsound as a matter of logic. The theist God is defined as one that interacts in the natural world.

75. Stenger, supra note 11, at 121 ("The Creator, if he existed, left no imprint. Thus he might as well have been nonexistent.").

76. It would require us to provide evidence that would both not be requested in any other setting but it also would not provide any positive proof whatsoever for the existence of God. See HARRIS, supra note 11 .

77. See text accompanying footnotes $52-56$.
} 
2. How were galaxies, stars, planets, and other cosmic entities formed?

The Standard (Inflationary) Model of Cosmology explains in rich detail the history of the cosmos from fractions of a second after the Big Bang to the present day. We know that a violent eruption of enormous energy and heat gave birth to our universe ${ }^{78}$ After roughly a billion years, as the universe continued to cool and expand, gravity clumped the primordial elements together to form larger and more complex systems such as galaxies, stars, and eventually planets. $^{79}$

Through direct observation, the predictions of the Big Bang made by theoretical physicists have been confirmed to a remarkable degree of accuracy ${ }^{80}$ In observations by astronomers, physicists' predictions have been "right on the mark." ${ }^{81}$ As Brian Greene mentions, "[this] is impressive almost to the point of hubris. All the data we possess confirm a theory of cosmology capable of describing the universe from about a hundredth of a second [after the Big Bang] to the present, some 15 billion years later." ${ }^{82}$

Physicists readily acknowledge that while these measurements give us a remarkable degree of confidence in what has occurred since moments after the Big Bang, they tell us very little about what occurred before the so called Planck length. ${ }^{83}$ As such, physicists probe deeper and earlier through the use of theoretical tools, such as String Theory, Superstring Theory, and M-theory for answers. There are, of course, other mysteries as well. Questions such as what is the nature of time? What is dark energy and how does it relate to the expansion of the universe? What is dark matter and why does it make galaxies rotate so strangely? This is where the true mysteries in physics and astronomy

78. GREENE, supra note 72 , at 346-70.

79. Id. at 347 .

80. Id. at $348-49$

81. Physicists predicted the abundance of light elements produced moments after the big bang. The theory also predicts that the entire universe is filled with a faint "cosmic background radiation" and that the universe is expanding. With the help of microwave radios and massive, powerful telescopes, astronomers have confirmed each of these predictions. See id. at 348-49.

82. Id. at 349-50; STENGER, supra note 11, at 128-29 (explaining that there has never been an event in the cosmos that has been glimpsed by our best astronomical instruments that can't be explained on natural terms).

83. GReEne, supra note 72, at 350 (stating that the Planck length is known as the point when "gravity and quantum mechanics can no longer be treated as two separate entities as they are in pointparticle quantum field theory." Instead, other tools, such as string theory, must be used to gaze inside.). 
lie. ${ }^{84}$ The belief that complex systems such as galaxies, stars, and planets were created from this process however, is not seriously questioned. ${ }^{85}$

Following my discussion in the previous section, if the mysteries that remain are used as a rationale for the existence of God, the God that emerges is fundamentally different than the theist God; instead, He looks more like the fundamental laws of physics. We see that the process that led to the formation of galaxies, stars, and planets is a gradual one without "ontological discontinuities."

\section{How did life on Earth begin?}

To suggest that the question of how life originated on Earth is settled would be an overstatement of the highest order. In fact, the very definition of life is a highly contentious issue. Some limit life to a chemical process, others allow for computer bits to qualify as living, and yet others see life in any substance that decreases in entropy. ${ }^{86}$ To simplify this discussion, I will use NASA's "working definition" that life is "a self-sustaining chemical system capable of Darwinian evolution." ${ }^{87}$ It should be noted, however, that one might, just as easily, choose a definition that is more ephemeral. For example, the immanent physicist, Erwin Schrodinger, defines life as that which "selfassembles against nature's tendency towards disorder, or entropy." "This

84. Douglas N.C. Lin, The Genesis of Planets, SCI. Am., May 2008, at 50 (describing the formation of planets as a chaotic process that can produce great variety in the kinds of planets that form).

85. CARl SAGAN, Cosmos 225 (Random House 1980) ("Stars and their accompanying planets are born in the gravitational collapse of a cloud of interstellar gas and dust."). See also DAwKINS, GoD Delusion, supra note 11, at 142 (Fred Hoyle worked out how hot temperatures, deep inside stars, forge most of the heaviest elements. When these big stars explode as supernovas, they scatter their materials in dust clouds, which eventually condense to form new stars and planets.).

86. Gerald Joyce defines life as "a self-sustaining chemical system capable of Darwinian evolution." This is the "working definition" also adopted by NASA. Pier Luigi Luisi, About Various Definitions of Life, 28 Origins of Life and Evolution of the Biosphere 613, 617 (1998). See also Alonso Ricardo \& Jack W. Szostak, The Origin of Life on Earth, 301 SCI. Am., Sept. 2009, at 56. There are numerous definitions given for "life," each revealing a different perspective. A physicist, Erwin Schrodinger, suggests that "a defining property of living systems is that they self-assemble against nature's tendency toward disorder, or entropy." Ricardo \& Szostak, at 56. Another definition, created by Carl Sagan and adopted by Encyclopedia Brittanica, defines life as "a localized region that increases in order (decreases in entropy) through cycles driven by an energy flow." See also Robert Shapiro, Small Molecule Interactions Were Central to the Origin of Life, 81 Q. Rev. Biology 105 (2006).

87. Luisi, supra note 86.

88. Ricardo \& Szostak, supra note 86, at 56; see Erwin Schrodinger, What Is Life?: The Physical Aspect of the Living Cell (Cambridge Univ. Press 1967) (1944). 
definition is so inclusive that under it, even fire might be considered alive.$^{89}$ The point here is that life truly is what you make of it.

Even if we agree on limiting life to a chemical process, there is still great disagreement among scientists as to how it arose. It is important to note that the ongoing debate over the origin of life does not relate to a paucity of theories. On the contrary, there is an abundance of theories as to how life might have arisen out of a gradual process. Theories such as DNA-first, ${ }^{90}$ RNA-first, ${ }^{91}$ and metabolism-first ${ }^{92}$ have all been considered, but the sheer

89. For a good discussion on the question of whether fire is alive, see JoHn MAYNARD SMITH \& Eors Szathmary, The Origins of Life: From the Birth of Life to the Origin of Language 5-6 (Oxford Univ. 2000).

90. DNA, which is made of nucleotides, carries instructions on how to create a protein. And proteins, through the use of enzymes, carry out the instructions encoded in DNA. DNA therefore cannot operate without proteins and proteins are aimless without DNA. Which then came first? See Shapiro, supra note 86 , at 47 .

91. In the 1980s, a new candidate for Earth's first "living material" emerged in the form of RNA. Scientists discovered that RNA, like DNA, conveyed information to substances that constructed proteins. In addition, scientists discovered a substance called ribozymes which was not only made of RNA but also helped catalyze the construction of more RNA. To many chemists, this helped solve the chicken-or-egg problem; RNA both encoded instructions and "catalyze[d] the synthesis of [itself]." According to this model, life arose with the first self-replicating RNA. Shapiro, supra note 86, at 48; see also Walter Gilbert, Origin of Life: RNA World, 319 NATURE 618 (1986) ("One can contemplate an RNA world, containing only RNA molecules that serve to catalyze the syntheses of themselves.").

However, problems with this theory were soon pointed out. First, despite repeated attempts, nucleotides, the building blocks of RNA, could not be created in a lab. Shapiro, supra note 86 , at 48 . Of the amino acids that were successfully created in a lab, none reached the level of complexity of a nucleotide. Furthermore, while some of life's building blocks (i.e., amino acids) have been found on meteorites, no nucleotides have ever been discovered there. Id. at 49. Because of RNA's complexity, Robert Shapiro has concluded that the sudden emergence of RNA was an "extremely improbable event," one that is too improbable to be given too much weight. Id. at 117; but see John Sutherland et al., Synthesis of Activated Pyrimidine Ribonucleotides in Prebiotically Plausible Conditions, 459 NATURE 239 (2009) (reporting the synthesis of two ribonucleotides, the basic ingredients of RNA); see also Nicholas Wade, Chemist Shows How RNA Can Be the Starting Point for Life, N.Y. Times, May 13, 2009.

It is additionally suggested that perhaps a simpler replicator arose first and eventually, RNA completely took over its role. According to Shapiro, the problem with this possibility is that one would have to explain how this simpler molecule "spontaneously assembled" itself into RNA. This, however, may be more implausible than even the organic assembly of nucleotides. Shapiro, supra note 86, at 49-50. However, the RNA-first theory has recently been given a significant boost by the creation in a lab of two of the four basic building blocks of RNA. See Sutherland et al., supra note 91.

92. The alleged improbability of the RNA-first model has led other chemists to speculate that life arose in a pre-biotic, metabolic process. In this model, compounds draw from free energy in the environment to catalyze a self organizing cycle. In other words, non-genetic material interacts to create larger and more complicated compounds. Stored within a membrane, these compounds can evolve and grow through the acquisition or the creation of new components. Shapiro, supra note 86 , at 117 . These compounds would then reproduce whenever "physical forces split the enlarged system into two or more fragments." Id. Although this model also posits a complicated chain reaction of events, its proponents claim that, due to the small molecules involved in the process, it is more probable than the alternative. $I d$. at 
complexity of each process has lead chemists to doubt each one. Similarly, the disagreement goes far beyond these camps and extends to a wide range of theories, such as PNA-first, ${ }^{93}$ the Clay Theory,,${ }^{94}$ and the fascinating possibility that life first appeared in a meteor from outer space. Regardless of which theory, if any, is correct, it is instructive to understand where the debate is currently taking place. Without a semblance of doubt, the question of the origin of life is the province of chemists and perhaps biologists, and the debate is taking place in their scholarly exchanges. It is unimaginable that a religious mind, untrained in these disciplines, would have anything to contribute to the debate. ${ }^{95}$ But the idea that life arose through divine intervention, and not as a gradual process, is not something that, to the best of my knowledge, chemists or biologists seriously consider.

The possibilities are actually more exotic than even the theories referred to above suggest. A single cell would certainly qualify as being "alive," ${ }^{, 6}$ so long as it had the requisite Darwinian qualities. ${ }^{97}$ Yet, each of the theories discussed above delves into the time period before the formation of the first cell. ${ }^{98}$ The biochemist Carl Woese, winner of the biosciences equivalent of the Nobel Prize, throws a monkey wrench in the entire process. He argues that

117-18 (There exists a great deal of disagreement, even among proponents of metabolism first models. These disagreements concern 1) the source of the energy, 2) the most favorable location, 3) the barrier than would contain the compounds, 4) the source of organic materials, and 5) the character of the reactive chemical system.). Id. at 118 .

As with RNA-first however, the metabolism first model must overcome a number of significant hurdles. First, it has been pointed out that there is no experimental evidence to support this model and the evidence that does exists, suggests that metabolic systems are rather "fragile and easily destroyed." Additionally, according to Addy Pross, it appears that the sudden emergence of an ordered system, unlinked to any other process, would violate the Second Law of Thermodynamics. See Addy Pross, Causation and the Origin of Life: Metabolism or Replication First?, 34 Origins of Life And Evolution IN THE BIOSPHERE 312 (2004).

93. Peter Nielsen, A New Molecule of Life?, 299 SCI. AM. 64 (Dec. 2008) (arguing that because of its information-storage properties and its chemical stability, peptide nucleic acid might have served as primordial genetic material at the origin of life).

94. Ricardo \& Szostak, supra note 86 , at 54, 58-59; see also Clay Minerals and the Origin of LIFE (Graham Cairns-Smith \& H. Hartman eds., 1987).

95. Notwithstanding, Pope John-Paul II argued in 1996 that there was an "ontological discontinuity" between man and ape. Something special, presumably with the assistance of the theist God, occurred when man acquired self-consciousness, self-awareness, or a moral conscience. Pope John Paul II, supra note 68, at $\S 6$.

96. See Ricardo \& Szostak, supra note 86, at 56 (Definitions range from those based on thermodynamics, to chemistry, to cybernetics. NASA's working definition of life is a "self-sustaining chemical system capable of Darwinian evolution.").

97. Such as metabolic activity and the ability to replicate.

98. The first single cell prokaryotes date to roughly 3.5 billion years ago. 
early cell designs must have been simple and poorly organized so that cellular components could be easily altered or stolen by "horizontal gene transfer." 99 The horizontal transfer of information, as opposed to vertical, was then the principle driver of cell evolution. ${ }^{100}$ According to this view, the haphazard exchange of information, i.e. genes, in the sea of clumsily-organized primitive cells, led to the evolution of ever more complex forms. ${ }^{101}$ With sufficient mixing, blending and re-combinations, one of the traits that would eventually evolve is the ability to successfully resist the acquisition of your components by other "cells." 102 The cell thereby undergoes a gradual shift from being "completely ephemeral to being increasingly permanent." ${ }^{103}$ At some arbitrary point in that process, it can be declared that life emerged.

It is exceedingly likely that due to the sheer complexity of the process, we may never know precisely how life emerged. These facts may be forever lost to the past. What is certain though, is that the question is not one of metaphysical proportions; but rather, merely one of chemistry and the evolution of stable compounds. ${ }^{104}$ If God emerges somewhere in this process, $\mathrm{He}$ is likely to take the form of the laws of thermodynamics. ${ }^{105}$

99. Carl Woese, On the Evolution of Cells, 99 Proceedings of the National Academy of Sciences of the United States of America 8742, 8743 (2002) [hereinafter Woese, On the Evolution of Cells]; see also Carl Woese, The Universal Ancestor, 95 Proceedings of THE NATIONAL ACADEMY of SCIENCES OF THE United StATES OF AMERICA, 6854 (1998) [hereinafter Woese, The Universal Ancestor].

100. Woese, On the Evolution of Cells, supra note 99, at 8744.

101. Id.

102. Id.; The question of life's origins is more generally a question about stability and heredity. Everything that we see around us is in effect a pattern of stable atoms. If they were not stable, they would dissipate and not be worth mentioning. As Dawkins mentions, "[t]he earliest form of natural selection was simply a selection of stable forms and a rejection of unstable ones. There is no mystery about this. It had to happen by definition." Dawkins, Universal Darwinism, supra note 44 , at 14 . Cairns-Smith \& Hartman, supra note 94, at 16 ("There could have been nothing at all sudden about the origin of life on the Earth. That somewhat ill-defined collection of strange attributes that now we can so easily recognize as 'life' would have emerged only slowly as explicitly the product of evolution through natural selection.").

103. Woese, On the Evolution of Cells, supra note 99, at 8744 (The view of life that thus emerges is one where the "universal ancestor is not a discrete entity ... [but rather] a diverse community of cells that survives and evolves as a biological unit."). Woesse, The Universal Ancestor, supra note 99, at 6854.

104. See, e.g., Sutherland et al., supra note 91, at 139, 239-42 ("At some stage in the origin of life, an informational polymer must have arisen by purely chemical means."); see also Woese, On the Evolution of Cells, supra note 99.

105. Thermodynamics is essentially the study of everything above the quantum level. More precisely, it is a set of laws that govern the activity of heat, energy and, by extension, all matter. This includes the "tendency of atoms and molecules to react; to bind, absorb, or partition; to dissolve or change phase; or to change their shapes or chemical bonds." See Ken Dill \& Sarina Bromberg, Molecular Driving Forces: Statistical Thermodynamics in Chemistry and Biology 105 (2002). 


\section{How did humans originate?}

It is now incontrovertible that the human lineage diverged from chimpanzees some 5 to 7 million years ago. There still exist numerous questions as to how and when chimpanzees evolved into Australopithecines and eventually into Hominids. There also exists the compelling question of the extent to which Neanderthals and early humans competed for territory and the fascinating, and controversial, question of whether or not they mated. ${ }^{106}$ Regardless of how these questions are resolved, the evolutionary framework within which these questions arise is unlikely to be discarded. It may be tweaked and refined, but by and large, there is overwhelming evidence to suggest that the evolutionary framework is accurate and sound. As Daniel Dennett states, "evolution is about as well established as the fact that water is $\mathrm{H}_{2} \mathrm{O}$." 107

At the time when Darwin published Origin of Species, no fossil record existed linking humans to our chimpanzee cousins. ${ }^{108}$ In the past 150 years however, there have been a substantial number of fossil discoveries. ${ }^{109}$ The fossil record though, is far from complete; it becomes more incomplete as one looks further into the past. ${ }^{110}$ Yet, there have been numerous discoveries of intermediary fossils between humans and our more ape-like predecessors, the australopithecines. As one goes back in time, the fossils show a consistent "devolution" of a more protruding jaw, a larger brow, a receding forehead, shorter legs, a smaller cranium, and many other physical qualities that one would expect. ${ }^{111}$

106. Apparently, this question may not be so controversial anymore. See Nicholas Wade, Signs of Neanderthals Mating With Humans, N.Y. Times, May 6, 2010 (reporting on research suggesting that humans and Neanderthals did indeed mate).

107. Dennett, Breaking the Spell, supra note 11, at 60.

108. Richard Dawkins, The Greatest Show on Earth 183 (2009) [hereinafter Dawkins, Greatest Show].

109. Id. at $183-97$.

110. If a complete fossil record existed however, it would be impossible to distinguish one species or genus from another. Ostensibly, each child would be categorized in the same species as its parents. Following the full fossil record, each individual would then be placed in the same category from the first hominid to modern man. However, it is the absence of a full fossil record that allows us to categorize fossils into discrete species and genera. As Darwin mentions, "[i]n a series of forms graduating insensibly from some apelike creature to man as he now exists, it would be impossible to fix on any definite point where the term 'man' ought to be used." Id. at 196. (1999).

111. See, e.g., Richard Klein, The Human Career: Human Biological and Cultural Origins 
If the fossil record leaves too many gaps unfilled, then the genetic record should seal the argument. Long before genetic evidence existed - in fact, even before fossil evidence existed-biologists surmised that humans were related to the great apes and to all other living creatures. ${ }^{12}$ More recently, the relationship has been further confirmed by geneticists peering into the genetic code. This research has authoritatively confirmed that humans and chimpanzees are $98 \%$ related. ${ }^{113}$ If the genetic evidence would have revealed inconsistencies in the evolutionary narrative, the entire theory would need to be discarded. ${ }^{114}$ However, the genetic evidence looks much the way evolution predicts; humans are related to apes, which in turn are related to lemurs, to mice, to lizards, to fish, to sea urchins, to jelly fish, to sponges, to algae, and to bacteria. This is all confirmed by the genetic evidence. That which distinguishes one species from another is not a distinction as a matter of kind; it is merely a matter of degrees. ${ }^{115}$

\section{How did our moral sense originate?}

In 1996, Pope John Paul II addressed the Pontifical Academy of Sciences and stated that there was an "ontological discontinuity" between man and ape. ${ }^{116}$ Something special, with the assistance of the theist God, occurred when man entered the spiritual realm and acquired a soul. ${ }^{117}$ According to the Pope, after this point, man acquired a moral sense, self-consciousness, metaphysical knowledge, and an appreciation for the aesthetic.

The Pope declares that the church had an interest in the topic of evolution because it touches on matters that fall "within her own proper sphere of competence." "118 particular, evolution strongly implies that the "spiritual"

112. Initially, the relationship between man and ape was established by mere physical resemblance. Later, it came to be confirmed by the fossil evidence just discussed. See Dawkins, Greatest Show, supra note 108 , at 183 .

113. See Matt Ridley, Genome 24-28 (1999) (noting that the most obvious difference between humans and apes is that apes have 24 chromosomes while humans have 23 . The second largest human chromosome is actually a fusion of two medium-sized ape chromosomes.).

114. Dawkins, God Delusion, supra note 11, at 127-28.

115. Speciation is determined by asking whether two animals are able to reproduce successfully. However, there are a number of ambiguous, indeterminate cases that make it very difficult to precisely determine whether animals belong to separate species. See Kevin De Queiroz, Species Concepts and Species Delimitation, 56 Systematic Biology 879 (2007) (discussing the various difficulties of precisely defining the concept of a "species").

116. Pope John Paul II, supra note 67, at $\S 6$.

117. Id. $\S \S 5-6$.

118. Id. $\S 3$. 
sense to which the Pope alludes emerges through the unguided hand of natural selection. This conflicted directly with the church's belief that such a spiritual sense could only emerge through God's helping hand. ${ }^{119}$ A clear split between religion and science was set.

To rehash an earlier point, since it is impossible to prove the nonexistence of anything, ${ }^{120}$ it is impossible to prove the non-existence of the human soul. However, since the Pope, in the same address, lists the constituent parts of the human soul, it is possible to discuss evolution's contribution to each isolated part. ${ }^{121}$ The Pope asserts that the human soul is comprised of "the experience of metaphysical knowledge, of selfconsciousness and self-awareness, of moral conscience, of liberty, or of aesthetic and religious experience." I will address each one of these pieces in turn. I will dedicate the rest of this section to discussing the origins of morality. Consciousness and liberty, I will address in subsection 6. It is unclear to me that religious experience and metaphysical knowledge are in any way different and for that reason I will treat them together in subsection 7. As will be shown, evolution has a great deal to contribute to the origin of the "spiritual" sense.

Genes ensure their survival and reproduction into new generations by enlisting the help of the organisms they inhabit. ${ }^{122}$ While a gene is commonly thought to behave "selfishly," it can sometimes find its way into a larger number of offspring by "convincing" an individual to act altruistically towards others. There are four commonly recognized conditions under which this will occur. First, kin selection relates to altruism shown to individuals you are genetically related to such as, offspring, ancestors, and siblings. As a general rule, the stronger the genetic connection, the stronger the level of altruism. ${ }^{123}$ A gene that encourages an individual to help out a brother-who would thus share a large percentage of the individual's genes-would increase the

119. Id. $\S 5$ (Philosophies that "regard the spirit either as emerging from the forces of living matter, or as a simple epiphenomenon of that matter, are incompatible with" religious doctrine.).

120. See supra text accompanying note 76 .

121. According to Pope John Paul II, "the experience of metaphysical knowledge, of selfconsciousness and self-awareness, of moral conscience, of liberty, or of aesthetic and religious experience" can only be illuminated by "philosophical reflection" and not through the study of evolution. Pope John Paul II, supra note 67, at $\S 6$.

122. See Dawkins, Universal Dar Winism, supra note 44.

123. Dawkins, Universal Darwinism, supra note 44, at 94. Dawkins gives the example of haplidoploids (bees, wasps, and termites) who, because of the way they reproduce, have offspring that are $75 \%$ related to each other. Given their high level of genetic relatedness, the fact that these insects are extremely social should not be a surprise. $I d$. at 174-76. 
likelihood of the gene being passed down to a subsequent generation. ${ }^{124}$ Through this logic, a "selfish" gene may spread itself more effectively by encouraging an individual to behave altruistically.

A second rudimentary form of morality is referred to as reciprocal altruism or symbiosis. According to this form of altruism, if there is both an asymmetry of needs and skill and a likelihood that your charity will be repaid, individuals will give each other a helping hand. ${ }^{125}$ The natural world is filled with these mutualistic relationships, such as: cleaner fish and groupers, flowers and bees, buffaloes and oxpeckers, cows and their gut microorganisms, and plenty more. ${ }^{126}$ The individuals in these relationships need not do a rational cost-benefit analysis; their genes have pre-programmed them to act altruistically.

Another form of altruism may be called reputational altruism. In certain, close-knit societies, it may be advantageous to develop a reputation for being altruistic. ${ }^{127}$ In a time of need, perhaps your previous generosity will be repaid. Last, being generous to others may be an "unfakable" way of advertising your own superiority. ${ }^{128}$ This proves to be an effective way for male birds to convince females that they will make excellent mates. ${ }^{129}$

What is particularly intriguing about each of these four Darwinian examples of altruism is that the conditions under which prehistoric humans lived lend themselves neatly to the evolution of these impulses. Humans lived in small bands isolated from neighboring groups. ${ }^{130}$ Under these living conditions, it is exceedingly likely that an individual would be related to many other members of the troupe. ${ }^{131}$ The conditions would be ripe for the

124. $I d$. at $88-108$ (discussing kinship altruism in greater detail and concluding that actual relatedness may be less important than the "best estimate of relatedness").

125. For a clear and succinct discussion on reciprocal altruism, see DAWKINS, God DELUSION, supra note 11, at 216-18. For a richer discussion on reciprocal altruism, including the historical development of the concept and the presence of "cheats," see DAWKINS, UNIVERSAL DAR WINISM, supra note 44, at 202-33.

126. See Dawkins, God Delusion, supra note 11, at 216-17 (The phenomenon of symbiosis is widespread in nature. For example, the flower uses the bee to pollinate its seed and the bee is paid off in nectar; birds called honeyguides search for beehives and honey badgers break into them, they both benefit.).

127. Dawkins, God Delusion, supra note 11, at 218.

128. Amotz Zahavi, Altruism as a Handicap: The Limitations of Kin Selection and Reciprocity, 26 J. OF AVIAN BIOLOGY 1 (Mar. 1995) (arguing that an altruism "handicap" communicates an individual's honest willingness to enter into a collaboration).

129. Dawkins, Universal Darwinism, supra note 44, at 159-60, 309-13 (Initially, Dawkins doubted this "handicap" theory of altruism but in a later edition, he included a lengthy footnote discussing the findings that vindicate this theory.).

130. Dawkins, God Delusion, supra note 11, at 220.

131. Id. 
emergence of kin altruism. ${ }^{132}$ One would also tend to regularly come across the same individuals thus bolstering the ability of reciprocal altruism to evolve. ${ }^{133}$ Additionally, these would also be the ideal conditions for reputational altruism and for advertising your superiority to take hold. ${ }^{134}$ The roots of morality therefore, are the product of Darwinian evolution.

This view of the origin of morality is certainly discomforting to those who prefer to think of morality as somehow intrinsically good. What these examples point out however is that a moral sense may instead be instrumentally good. ${ }^{135}$ For instance, sweets, which provided a cheap source of energy, helped evolve a "sweet tooth" tendency in humans. ${ }^{136}$ However, Daniel Dennett points out that if rolling around in elephant carcasses, as a vulture would, would have improved our reproductive fitness, a "dead elephant would smell as sweet as rose to us." ${ }^{137}$ Our intuitions of what is intrinsically so - i.e. sugar tastes good — are dependent on its usefulness to us in our evolutionary history. In this same way, altruism helped our genes spread themselves more effectively. Morality was instrumental to our ancestors' (or their genes') reproductive success.

In an attempt to better understand which moral decisions people make and how they rationalize them, researchers have posed various moral dilemmas to people and analyzed their responses. Through the use of surveys, Hauser and Singer compare moral intuitions across distinct cultures and find that humans' moral judgments are extraordinarily similar. ${ }^{138}$ After posing a set of challenging moral dilemmas, respondents give similar answers in $90 \%, 97 \%$, and $97 \%$ of the questions asked, respectively. ${ }^{139}$ Perhaps even more

132. $I d$.

133. $I d$.

134. $I d$.

135. See Dennett, Breaking the Spell, supra note 11, at 69.

136. $I d$. at 82 .

137. Id. at 69 .

138. Marc Hauser \& Peter Singer, Godless Morality, Project Syndicate (Jan. 4, 2006), available at http://www.project-syndicate.org/commentary/hausersinger1/English.

139. The survey asks respondents to fill in the blank morally "obligatory," "permissible," or "forbidden" in the following scenarios:

1. A runaway trolley is about to run over five people walking on the tracks. A railroad worker is standing next to a switch that can turn the trolley onto a side track, killing one person, but allowing the five to survive. Flipping the switch is

2. You pass by a small child drowning in a shallow pond, and you are the only one around. If you pick up the child, she will survive and your pants will be ruined. Picking up the child is

3. Five people have just been rushed into a hospital in critical care, each requiring an organ to survive. There is not enough time to request organs from outside the hospital. There is, however, 
interestingly, they find that people struggle mightily to justify and explain their moral judgments. ${ }^{140}$ These surveys, along with other research on morality, lead Hauser and Singer to conclude that there is growing empirical support "for the idea that, like other psychological faculties of the mind, including language and mathematics, we are endowed with a moral faculty that guides our intuitive [moral] judgments."

It is of course not implied that all of our moral judgments are determined by our genetically-inscribed intuitions. It is widely recognized that reason plays an important role in these decisions as well. Similarly, it should not be assumed that our genetic predispositions necessarily help us answer the normative questions of whether it is right or wrong. On the contrary, it is urged that we come to understand our intuitive moral tendencies so that we may act against them when necessary.

In this subsection, I only hope to make the limited point that Pope John Paul II was wrong when he stated that our moral faculty could only have originated through divine intervention. As many animals act altruistically, it is quite obvious now that our moral intuitions have deep evolutionary roots and that they therefore evolved through a gradual process. A theist God is unnecessary to explain morality's origin.

\section{What are consciousness and free will and how did they arise?}

The exciting possibilities of neuroscience are leading scores of young scientists to study the inner workings of the human brain. The hope is that a firmer understanding of the neural connections in the brain will help us better know who we are and why we behave in certain ways. ${ }^{142}$ Along the way, perhaps lingering philosophical questions such as the nature of consciousness and free will can be more fully understood.

Just as every other organ or creature in nature, the brain has evolved over time from relatively simple beginnings to today's complex structure. As with any evolved creature, the process has been one of trial and error and of fits and starts. However, there is a clearly discernible characteristic of the brain's

a healthy person in the hospital's waiting room. If the surgeon takes this person's organs, he will

die, but the five in critical care will survive. Taking the healthy person's organs is

Id.

140. $I d$.

141. $I d$.

142. See David Brooks, The Young and the Neuro, N.Y. Times, Oct. 13, 2009, at A31 (discussing the rush of young scientists choosing to study neuroscience because of the promise it holds for answering age-old questions). 
design. The oldest regions of the brain are found closest to the spinal cord, and newer regions were progressively built atop this foundation. Thus the brainstem, which controls "extremely basic" functions such as blood pressure and breathing, connects directly to the spinal cord. ${ }^{143}$ As you work your way up and around from the brainstem, the regions of the brain are responsible for progressively higher level functions such as coordinating body movements, processing emotions, and processing visual, touch, and muscle sensations. ${ }^{144}$ The last region of the brain to evolve, the frontal cortex, allows for logical reasoning, language, and the use of symbolic associations. ${ }^{145}$

As the brain evolved, it refined our capacity to process information from the environment, make predictions about the future, and take precautionary measures if necessary. The frontal cortex, the last region of the brain to evolve and the one responsible for making us distinctly human, greatly enhanced our ability to perform these functions. This "higher order" ability constituted a significant improvement over the limbic system's fight-or-flight emotional

143. David Linden, The Accidental Mind: How Brain Evolution Has Given Us Love, Memory, Dreams, AND God 7-8 (2007).

144. Id. at 7-21.

145. Id. at $18-19$. There are six separate regions of the brain. The brainstem controls vital functions such regulation of heart rate, blood pressure, breathing rhythm and body temperature. It also functions as a relay system for sensations coming from your muscles and skin as well as commands from the brain to other parts of the body. Slight damage to the brainstem will usually render you comatose while significant damage will usually lead to death. $I d$. at 7-9.

The cerebellum is "richly interconnected" with the brainstem and uses the signals relayed through the brainstem to coordinate our movements. If you sustain damage to the cerebellum, it will result in "clumsiness in performing simple tasks" such as walking, grasping and other activities. Id. at 9-13.

The midbrain is an "archaic system" that has been virtually supplanted by higher regions in humans. In some animals, the midbrain is the main sensory center but in humans, that function has been taken over by the cortex. Since it is not connected to higher parts of the brain, it plays a very limited role in humans. Damage to the midbrain causes the phenomenon of "blindsight." Id. at 13-15.

The thalamus is primarily a relay station for sending sensory information to and from higher parts of the brain. The hypothalamus, lying below the thalamus, is responsible for maintaining the status quo within the body such as activating shivering when the body gets cold, or activating hunger or thirst when the body needs food or water. One result of damage to the hypothalamus is overeating. Id. at 15-16.

The limbic system is a circuit of connections within the brain that controls emotions and certain kinds of memory. This system has two particularly important components, the amygdala and the hippocampus. The amygdala links information that is processed in other parts of the brain with emotion responses such as fear and aggression. The hippocampus is a memory center that stores information for approximately 1 year, before it is moved to another region in the brain. Damage to the hippocampus may result in a loss of memories of facts and events that occurred 2 to 4 years prior and it may prevent you from creating new memories. Id. at $16-17$.

Finally, the cortex is the outer surface of the brain and is separated into two sections. The back portion of the cortex is responsible for analyzing information coming from the senses. The frontal cortex is responsible for allowing us to make association between concepts and is the portion responsible for allowing individuals to develop "personalities." Id. at 18-21. 
response. ${ }^{146}$ It is this ability that likely led humans to also evolve consciousness and free will.

It is safe to assert that there was a survival advantage to animals that developed accurate models of the natural world. ${ }^{147}$ The better we understand the world, the better we can predict the future and manipulate it to our advantage. Daniel Dennett's theory of the intentional stance ${ }^{148}$ helps us understand how the competition between individuals could trigger an evolutionary arms race $^{149}$ that would lead to more accurate models and eventually to consciousness. ${ }^{150}$ For instance, a potential prey may instinctively flee at the sight of a potential predator. If the prey flees without a moment's thought, this is called first-order intentionality. The predator however can outsmart the prey by staying a step ahead. Perhaps the predator knows/believes that the prey will instinctively flee in a certain direction. This is called second-order intentionality because the predator formulates a belief (\#1) about the prey's intentions (\#2). By anticipating the prey's move, the predator is clearly in an advantageous position. The prey lineage however, could evolve the ability to also employ second-order intentionality. It could formulate beliefs about the predator's behavior and thus negate the predator's advantage. Over time, as predators and preys (or competitors within a species) compete for resources, those with greater cognitive capacities would clearly have a reproductive advantage.

146. See Susan Blackmore, The Meme Machine 202 (1999) ("We are designed by natural selection to be truth-seeking creatures. Our perceptual systems have evolved to build adequate models of the world and predict accurately what will happen next. Our brains are designed to solve problems effectively and to make sound decisions."). The ability to process a wide range of information from the environment and to make sophisticated calculations is indeed a vast improvement over the limbic system's emotional fight-or-flight capacity.

147. See Dawkins, God Delusion, supra note 11, at 182-83.

148. Daniel Dennett writes that when animals adopt the intentional stance,

they treat some other things in the world as: 1) agents with 2) limited beliefs about the world,

3) specific desires, and 4) enough common sense to do the right thing given those beliefs and

desires. Once animals began adopting the intentional stance, something of an arms race ensured,

with ploy and counterploy, deceptive move and intelligent detection of deceptive move, carrying animal minds to greater subtlety and power.

DenNetT, BREAKING THe SPELL, supra note 11, at 109-10.

149. An evolutionary arms race is one in which a lineage, say that of prey, acquires progressive improvements in adaptations as an evolutionary response to progressive counter-improvements in an enemy lineage, say that of predators. As Dawkins mentions, "[o]ne lineage will tend to evolve adaptations to manipulate the behaviour of another lineage, then the second lineage will evolve counter-adaptations." Richard Dawkins, The Extended Phenotype: The Long Reach of the Gene 61 (1982).

150. Dennett, Breaking the Spell, supra note 11, at 108-15. 
With the advent of more sophisticated brains, humans would have an even greater ability to model the natural world and to predict the future. ${ }^{151}$ With this ability, it is possible to get to third-order intentionality and to thus produce consciousness. For the rest of this example, substitute Bob and Charles for predator and prey, respectively. Always in need of staying one step ahead of competitors (particularly of intra-species competitors), perhaps Bob recognizes that Charles knows that Bob wants to corner him. By peering into Charles's mind and formulating a belief (\#1) about Charles's belief (\#2) about Bob's intentions (\#3), third order intentionality is reached and an endless loop develops. In other words, Bob's model of the natural world includes the existence of "other minds" that are also developing models of the natural world. ${ }^{152}$ By recognizing that your mind is just one of many other minds, consciousness is reached. ${ }^{153}$ Consciousness arises through the gradual evolution of ever more accurate models of the natural world.

Free will is closely tied to the question of consciousness. For, if we are not conscious of having made a decision, it is hard to imagine that it was "made" as a product of free will (however free will might be defined). Cognitive neuroscientist Michael Gazzaniga has shown that people can take information into account even when they are simply not aware of the information. For instance, he studied patients with damage to the brain's parietal lobe who experienced the phenomenon of "neglect." When these patients looked straight ahead, they denied seeing anything to the left of their focal point. ${ }^{154}$ Gazzaniga and his colleagues demonstrated that the patients could accurately identify whether the object in the left visual field (say, an apple) was similar to the object in the right visual field. Amazingly, the subjects were able to accurately state whether the two objects were similar even though they denied having seen the object in the neglected field. ${ }^{155}$ The

151. It is much more likely that the process would play itself out in the competition for resources within a species. The reason for this is that there are many external factors involved that would need to affect the lineages of both competitors. If it happened between a predator and prey, we would have to assume that each was exposed to these same environmental factors. For instance, the acquisition of higher cognitive capacities must be facilitated by factors such as constant interaction of individuals (such as in highly social animals), the ability to communicate verbally, the availability of protein (to feed the proteinhungry brain), and others. It is also possible that the process might be furthered by one or more random mutations. These mutations would have a way to make it into the genes of intra-group competitors but not into the genes of a separate species. Because of this, it is much more likely that this process was driven by competition within a species.

152. See, e.g., Theories of Theories of Mind (Peter Carruthers \& Peter K. Smith eds., 1996).

153. See Nicholas Humphrey, The Inner Eye 65-71 (2002).

154. Michael Gazzaniga, The Mind's Past 77 (1998).

155. Id. ("The patients performed this task accurately; but when they were questioned about the 
information is making its way into the brain but "it is being processed outside of conscious experience." 156

Perhaps even more spectacular is research showing that once humans become aware of their decisions, the brain works retroactively in time to "reconstruct" events so as to create the illusion that "we" are in control. ${ }^{157}$ This is most poignantly shown by the experience of split-brain patients. Splitbrain patients, usually in response to epileptic seizures, undergo an operation to disconnect the communication of the left and right cortexes. In a famous study by Gazzaniga, subjects were presented with two images such that each image would be received by only one visual field. ${ }^{158}$ The right visual field (thus the left cortex) received an image of a chicken claw and the left visual field (thus the right cortex) received an image of a winter scene. The patient was then asked to pick up a card that matched the image. The right hand (left cortex) chose a chicken (to match the chicken claw) and the left hand (right cortex) chose a shovel (to match the winter scene). When the patient was asked why he chose those two cards, the left side of the brain, which is the only one that "speaks," gave an answer. ${ }^{159}$ Since the left brain had only seen the chicken claw, the patient's response was that "the chicken claw goes with the chicken and you need a shovel to clean out the [chicken] shed." 160 Gazzaniga's study reveals that after a decision has been made, the brain will retroactively construct a narrative to have the decision make sense. ${ }^{161}$ As

nature of the stimuli after a trial, they could easily name the stimulus in their right visual field but denied having seen the stimulus presented in their neglected left field."). Id. at 78.

156. Id. at 77 .

157. Id. at $1 ; i d$. at xiii ("At first it is hard to believe that most of these devices [in the brain] do their jobs before we are aware of their actions. We human beings have a very centric view of the world. We think our personal selves are directing the show most of the time. I argue that recent research shows this is not true but simply appears to be true....").

158. Michael Gazzaniga, Principles of Human Brain Organization Derived From Split-Brain Studies, 14 Neuron 217 (1995).

159. Only the dominant side of the brain is responsible for speech. In most humans, it is the left side of the brain that "speaks." See Michael Gazzaniga, Mind Matters: How Mind and Brain Interact to Create Our Conscious Lives 12 (1988).

160. LindEN, supra note 143, at 227-29 (recounting Gazzaniga's study).

161. This is but one instance of the brain working backwards in time. Gazzaniga tells of a similar experiment where a seated split-brain patient is told to take a walk. This command, however, is communicated only to the person's "silent, speech-less" right cortex. As the person stands and starts to walk away, if they are asked to explain why they are doing so, the typical reply will be, "Oh, I need to get a drink." These examples reveal that people often make decisions without being conscious that such decisions were made. Additionally, the brain will sometimes provide explanations for actions after they are taken. Gazzaniga, The Mind's Past, supra note 154, at 133. Linden, supra note 143, at 96.

An additional line of research by Antonio and Hanna Damasio has revealed that brains are capable of doing complicated cost-benefits analyses and using the results to make decisions without the person 
Gazzaniga explains, the left brain simply "cooks up an explanation." ${ }^{162}$ Free will seems to have disappeared. ${ }^{163}$

As with virtually every empirical question, researchers have not provided a complete picture of what constitutes consciousness and to what extent free will exists. However, it is clear that no supernatural explanation is needed to explain consciousness; its origin is explained by evolutionary theory. As for free will, perhaps the Cartesian form of free will, that postulates an "I" inside our brains, does require a divine source. If this kind of free will existed, perhaps it would constitute an "ontological discontinuity." However, this is precisely the kind of free will that the experiments above reveal is plainly wrong. After we take into account the myriad environmental factors that influence our decisions and the fact that the brain is sometimes the last to find out about a decision, it is unclear what is left of free will. Since the brain begins to fire roughly half a second before we, for instance, move our finger, it has been suggested that all we can consciously do is prevent behavior that the brain has already decided to engage in. ${ }^{164}$ If this is correct, then perhaps free will is really "free won't." ${ }^{165}$ Either way, to the extent there is free will, it is not of the kind that requires the intervention of the theist God.

becoming conscious of it. Even more remarkable, in Antonio and Hanna Damasio's experiments, the patients' finger tips began to perspire whenever they pondered a risky decision but before the person explicitly knew that it was risky. It appears the fingers "knew" of the risk before the person did. Antonio Damasio et al., Deciding Advantageously Before Knowing the Advantageous Strategy, 275 ScI. 1293 (1997).

162. Gazzaniga, The Mind's Past, supra note 154, at 133.

163. The inner workings of the brain also cause us to question the "free-ness" of our decisions. All of the information in the brain is encoded by the firing of electrical spikes through an intricately connected network of brain cells, called neurons. Linden, supra note 143, at 39-47. An electrical signal travels through the cell body, through the axon, and it then has to "jump" through a gap, called a synapse, to reach the dendrite of the subsequent neuron. For the information to travel through the synaptic cleft (i.e. gap), the axon releases neurotransmitters which then reach the dendrite of the subsequent neuron. When the neurotransmitters reach the next neuron, the information is once again converted into an electrical signal and passed through the cell body, through the axon, through another synapse, and on to new neurons once again. This process however does not work so smoothly and its inefficiencies give us reason to question the extent to which we act willfully. LINDEN, supra note 143, at 44 .

As the signal travels through the brain, for some reason or another, it often fails to reach a subsequent neuron. For a single electrical spike, the average axon fails to release neurotransmitters into the synaptic cleft in perhaps as many as seven times out of ten. As such, it is difficult to determine which electrical signals will carry out the behavior that they have encoded. It is a matter of chance (mere probability) that will determine whether the stimuli actually lead to action. Some "thoughts" never turn into action. LINDEN, supra note 143 , at 44 .

164. Gazzaniga, The Ethical Brain: The Science of Our Moral Dilemmas 91-93 (2005).

165. Id. See also Daniel Dennet, Freedom Evolves 230-31 (2003) (quoting U.S. Ramachandran). 


\section{Why do we feel religious experiences?}

Of all of the reasons people have for believing in a theist God, perhaps the most powerful one is a personal experience that they have undergone. William James describes how "probably every religious person has the recollection of a particular crisis in which a director vision of the truth, a direct perception, perhaps, of a living God's existence, swept in and overwhelmed" them. ${ }^{166}$ Regardless of the existence or not of a theist God, these experiences are typically so powerful to the perceiver that they trigger a lifelong relationship between the individual and their God. ${ }^{167}$

The overarching point I hope to make in this subsection is merely that experiencing God does not require a violation of the laws of physics. Although religious experiences are real (as real as any other perception of the senses), they can be entirely explained by the memist God. Regardless of how vivid the religious experiences may be, they do not provide any proof either way, as to the existence of the theist God. Research from psychiatry drives home this point. It has been observed, for example, that many religious founders and leaders are documented as having or believed to have had epilepsy. ${ }^{168}$ In fact, the link between epilepsy and the divine has long been recognized. ${ }^{169}$ The ancient Greeks, in viewing epilepsy as a "sacred disease," widely believed that a person experiencing an epileptic seizure was being visited by the gods. ${ }^{170}$ Seizure victims report, for instance, that they felt an altered sense of reality, a sense of being in a dream state, and of being outside of themselves. ${ }^{171}$ They often describe the seizures as constituting deeply religious experiences and a small group even describe feeling a sense of unity,

166. JAMES, supra note 60 , at 75 . 60.

167. James recounts numerous accounts of profound religious experiences. See JAMES, supra note

168. Jeffrey Saver \& John Rabin, The Neural Substrates of Religious Experience, $9 \mathrm{~J}$. Neuropsychiatry \& Clinical Neurosciences 498, 500-02 (1997) (explaining that "[a] substantial number of founders of major religions, prophets, and leading religious leaders have been documented as having or suggested to have epilepsy." For example, Saint Paul, Muhammad, Margery Kempe, Joan of Arc, St. Teresa of Avila, Emanuel Swedenborg, Joseph Smith, Fyodor Dostoievky, and others); see also ATRAN, In Gods We Trust: The Evolutionary Landscape of Religion 188-89 (2002).

169. Saver \& Rabin, supra note 168, at 499.

170. Id.

171. $I d$. at 500-03. Interestingly, these are experiences also associated with electrical stimulation of the right amygdala and of the hippocampus. d'Aquili and Newberg argue that rhythmic rituals can stimulate the hippocampus and produce trance or dreamlike states. If the rhythms are of sufficient intensity, they may activate the hippocampus in the same ways as the effect of LSD use and produce hallucinogenic states. Eugene G. D’Aquili \& Andrew B. Newberg, The Mystical Mind: Probing the Biology of Religious EXPERIENCE 43-44 (1999). 
harmony and joy during the seizure. ${ }^{172}$ Perhaps it should not be a surprise that brain scans during deep "'mystical experiences' bear a striking resemblance to those recorded during bouts of temporal lobe epilepsy." "173

Scott Atran points out that "stressful events associated with existential anxieties," such as death, "motivate belief in the supernatural." 174 For instance, when responding to whether they believe in God's existence, subjects who were told a traumatic story reported higher levels of religiosity. This means that if subjects are primed with an emotional, stressful set of facts, they are more likely to remember them and to color the events with religious significance. ${ }^{175}$ Additionally, they will do so at higher rates than when they are primed with an emotionally-neutral or even an explicitly religious story. These studies strongly suggest that the extent to which a person interprets an event as religious, and thus has a religious experience, is dependent on whether anxiety is inherently present (such as with seizures or other traumatic situations) or whether it is evoked by the experimenter.

What the connection between religiosity and epilepsy and the connection between death-primes and religiosity reveal is that personal accounts of religious experiences do not present proof of the existence of the theist God. Without question, many normal, non-epileptic and non-primed people do indeed have deeply religious experiences, and the subjective profundity of these experiences should not be discounted. However, as evidence of the existence of a theist God that violates the laws of physics, they are thoroughly unreliable.

Not only does an evolutionary perspective provide an explanation for a wide range of natural phenomena but it also provides a framework for understanding why humans seem to be intuitively primed to believe in supernatural agents. One consistent finding of anthropologists has been that regardless of which human society is studied, they all have some concept of the supernatural. ${ }^{176}$ This suggests that religious inclinations run deep in the human lineage; it may even be a genetic predisposition. Daniel Dennett explains that the tendency to ascribe responsibility to a supernatural agent is likely a result of what he calls "hyperactive agent detector devices"

172. Id. at 503 (These experiences, called ecstatic seizures, however, are rare.).

173. ATRAN, supra note 168 , at 171.

174. Id. at 178-79; see also D'AQUILI \& NeWBERG, supra note 171, at 128 (discussing the relation between near death experiences and mystical, transcendental experiences).

175. ATRAN, supra note 168, at 178-79.

176. Pascal Boyer, Religion Explained: The Evolutionary Origins of Religious Thought (2001). 
(HADD). ${ }^{177}$ When, for instance, the wind rustles the leaves, Dennett argues that there is a strong asymmetry between false positives and false negatives. After hearing the noise, if an animal incorrectly assumes that it is another animal (maybe a potential predator) and scurries off, the consequence is that the animal may lose out on lunch. However, if an animal incorrectly assumes that the noise is simply the breeze (and not a potential predator), the consequences may be that he becomes someone's lunch. ${ }^{178}$ Evolution may thus strongly favor an instinctive predisposition to detecting agency even when it is not there. ${ }^{179}$

Lastly a belief in God often helps to answer questions about the afterlife. Because this does not relate to whether the theist God violates the laws of physics, I have excluded it from the discussion. ${ }^{180}$

177. Dennett, Breaking the Spell, supra note 11, at 116-19, citing Justin Barrett, Exploring the Natural Foundations of Religion, 4 Trends in Cognitive Science 31; see also Stew ARt Guthrie, Faces in the Clouds: A New Theory of Religion (1993).

178. Dennett, Breaking the Spell, supra note 11, at 109.

179. This might be an instrumental justification of Pascal's wager. It may pay to believe even when there is no God.

180. Discussing the afterlife is unnecessary for my argument that the theist God does not exist. Without this section, I would be able to proceed just the same to my analysis under the religion clauses. However, I include this note to address concerns some may have that I have overlooked an important aspect of belief in God.

Belief in an afterlife and in the human soul go together. For many, it is believed that when a person dies, their soul continues to exist in the spiritual world. The choices people have made and the personalities they have acquired in their lifetime are important considerations in the afterlife. In fact, they may determine whether one will be eternally saved or eternally damned. Because of the high consequences, the strength and fervor of religious beliefs are very much influenced by a person's belief in both an afterlife and in an insubstantial soul.

Scientific research however is making it increasingly difficult to promote the idea that a soul outlives the human body. Although I have provided a non-supernatural explanation for the origin of the soul's constituent parts, supra Part II.B.5-7, the brain sciences provide additional evidence to debunk the soul. Whatever it is that allows humans to have thoughts, feelings, experiences and awareness, it is clear that it resides in the brain. Researchers have extensively investigated virtually all of the basic components of human behavior and experience, such as moving, speaking, feeling, problem solving and much more. D'AQUiLI \& NEWBERG, supra note 171, at 45 . The conclusion to draw from this huge database of studies is that "no matter what happens to us or what we do, there is a part of the brain that becomes activated." $I d$. at 45 . To the extent therefore that there is a soul, it must pass through the brain. Id. See also Linden, supra note 143, at 47 and V.S. RAmachandran, A Brief Tour of Human Consciousness 3 (2004).

When a person dies, there is no longer any activity in the brain. While this would suggest that a person's soul has also died, it could be argued that instead, the soul has left for the spiritual world. Countless studies have shown however that when a part of the brain is damaged, the individual "no longer can do or experience the things that are mediated by that brain part." D'AQUILI \& NEWBERG, supra note 171 , at 45 . Without the hardware to perform the function, there simply is no function!

Another way to explain the basic importance of the brain's components is by understanding the brain's reaction to the ingestion of psychotropic drugs, such as LSD or peyote. These drugs hyper-activate the amygdala and hippocampus and thus induce hallucinations. D'AQUil \& NEWBERG, supra note 171, 


\section{Burden of Proof and the Evidentiary Standard}

Without question, for constitutional purposes, those who wish to debunk the existence of the theist God have the burden of proof. And even more importantly, given the special status that religion is accorded under the First Amendment, the evidentiary standard must be a very high one. Therefore, in order to teach, over the objections of angry parents, that the theist God does not exist, the issue must be a well-settled scientific principle. We might adopt the evidentiary standard from criminal law and conclude that the evidence must be persuasive beyond a reasonable doubt. ${ }^{181}$

There are certainly a number of scientists who believe in a theist God. ${ }^{182}$ This however, cannot be the standard for evaluating the persuasiveness of the evidence against the theist God. First, even people who are thoroughly logical in every aspect of their lives, somehow suspend the need for reason when the topic of God is discussed. ${ }^{183}$ Second, many people, including scientists, do not clearly define which kind of god they refer to when they mention God. Consequently, it is somewhat ambiguous whether their comments refer to the deist God, to the theist God, or to something else. Lastly, it may be that the

at 44; see also Saver \& Rabin, supra note 168 , at 505 . Not coincidentally, these are the same regions that are activated during deep religious experiences. Id. Regardless, drug use shows that your personality can change by altering the underlying mechanisms in the brain. Who you are as well as what you feel, experience, and think are entirely dependent on having the underlying mechanisms in the brain. If they do not function, it is impossible to develop that portion of your personality, and by extension, of your soul.

As with everything else, the non-existence of the human soul or of the afterlife cannot be entirely disproved. However, the evidence against them is overwhelming. The soul does not require a divine source. Supra Part II.B.5-7. All of what constitutes our personality (our "essence," if you will) is developed by and captured within the brain. Brain damaged patients confirm this view and show the exceptional extent that our personality is determined by the connection of neurons in the brain. Since there is no special quality or characteristic of the soul that is not captured by the brain, we can state with certainty that once the brain stops working, everything it holds inside disappears. Without a belief in a soul, it seems impossible to believe in the afterlife.

The preceding discussion excludes the pantheistic and naturalistic sense in which all energy is recycled so that when you die, your body becomes part of the lifecycle of Earth. Such a view of the afterlife does not require a violation of the laws of physics.

181. Although reserved only for criminal cases, I chose this standard because in our legal tradition, it is the heaviest standard to overcome. If it is fit enough to use in sentencing a man to death, it should be good enough for determining whether we can teach something in science class.

182. Paul Davies, The Mind of God: The Scientific Basis for a Rational World (1993); Francis Collins, The Language of God: A Scientist Presents Evidence for Belief 4, 14 (2006) (presenting a case for the existence of a God who "actively communicates with humankind and to whom one may pray in expectation of receiving an answer.").

183. HARRIS, supra note 11, at 11-14. 
non-existence of the theist God is an idea that is in the process of becoming the orthodox view. We should thus expect there to be many people who still believe otherwise. Regardless, the idea should be evaluated on its own merits. Here is a review of what we have covered.

Because it does not touch upon the existence of the theist God (as opposed to the deist God), we can safely bypass the question of why there is something rather than nothing. ${ }^{184}$ There is no serious doubt that galaxies, stars, and planets were formed through a gradual (although often violent) process and that it is explained by the laws of physics. ${ }^{185}$ If God exists in the remaining gaps, God is something akin to the fundamental forces. Next, the origin of life can be understood as a gradual process that eventually led to stable forms contained within a cell membrane. Pinning down the precise origin of life is, at worst, impossible, and at best, arbitrary. Although there is great uncertainty as to how this process occurred, the God that would emerge from these gaps looks something like the laws of thermodynamics.

It is now well accepted that humans are descendants of apes and distant cousins of every living organism on Earth. Similar to numerous other animals, we evolved an impulse to behave altruistically and to help our neighbors. It is not disputed that our moral sense is shaped by countless environmental factors and by our life experiences. But it is equally clear that our genes endow us with a primitive sense of right and wrong.

Finally, the brain might be the last great frontier in our understanding of how humans function. With the steady increase in brain imaging technology, there is great promise for the insights that neuroscience will reveal. We now know that brain activity occurs only when electrical impulses fire in the brain. Even then, it is uncertain to produce behavior or to make us conscious of it. While consciousness emerges from a gradual, evolutionary process, the experiments discussed above make it clear that free will is a much trickier concept than ancient philosophers supposed. It will be fascinating to see what the sophisticated technology and ingenious experiments of the future will bring.

As Darwinism is being used to answer some of the smallest and largest questions, the gaps in our understanding of the natural world are steadily closing. Throughout the process of substantiating scientific claims, if a single piece of evidence emerges that contradicts evolution, the entire theory would 
need to be discarded. ${ }^{186}$ However, despite assiduous searches, no such evidence has been uncovered. Through the use of the theory of evolution, we know that all that has occurred since the big bang has been through a gradual process and not through one with "ontological discontinuities."

Science has filled so many of the gaps in our understanding of the natural world that we can now confidently state that the world we live in resembles much more closely the one predicted by evolutionary theory. Therefore, we can confidently discard the theist God hypothesis as an explanation for natural phenomenon. Additionally, I believe there is sufficient evidence to refer to the competing theory, a world without the theist God, as accurate enough - in fact, extremely accurate — so that we may call it correct/true. ${ }^{187}$ Thus, we may safely declare that the particular aspect of the theist God that allows Him to violate the laws of physics is incorrect, as a matter of fact. ${ }^{188}$ I argue that there is no longer a reasonable doubt.

\section{The Theist God and the Religion Clauses}

Now that I have presented scientific evidence showing that it is overwhelmingly unlikely that the theist God exists, I am able to address the constitutionality of adopting the hypothetical series of textbooks. Essentially, the question is whether a public school can teach that the theist God, as distinct from the other kinds of Gods, does not exist.

186. Dawkins, God Delusion, supra note 11, at 127-28.

187. It might be argued that science does not prove that the theist God does not exist; however, it merely proves that observations correspond more closely with the non-theist God hypothesis than with the other. Thus, it may be argued that science teachers can only state that the data does not support the God hypothesis. While the premise of this argument is certainly accurate, the conclusion is flawed. It is true that science cannot proclaim any empirical matter as absolutely true. Given both the uncertainty that is inherent at the quantum level and the fact that it is known that much is still unknown about the universe, all scientific theories are somewhat tenuous. See supra text accompanying note 72, For example, science predicts that the Earth revolves around the sun and our observations have confirmed this theory. It is certainly possible that the heliocentric theory may be disconfirmed at some future date (perhaps if a fuller theory of gravity is ever developed) but it is highly unlikely that it will be. After an arbitrary point, if the likelihood of a theory being disconfirmed is extremely slim, we should be confident in declaring the theory as true. As with the heliocentric view, I argue that both the big bang and evolution are so strongly supported by our observations that they are extremely unlikely to be disconfirmed. They are accurate enough so that we may feel confident in calling them true. Since the theory that posits the existence of the theist God conflicts with these theories, we can feel equally confident calling it false.

188. As mentioned previously, this refers not to discarding the theist God in His entirety. It relates only to the attribute of the theist God that allows him to violate the laws of physics. Every other aspect of the theist God remains intact. See Part II.A. supra. 
The Supreme Court has consistently suggested that teaching the nonexistence of a theist God would violate the religion clauses. In County of Allegheny v. ACLU, Greater Pittsburgh Chapter, the Court stated that a secular state "is not the same as an atheistic or antireligious state. A secular state establishes neither atheism nor religion as its official creed." 189 The Court proceeded to state that the "Establishment Clause, at the very least, prohibits government from appearing to take a position on questions of religious belief." ${ }^{\prime 90}$ In a concurring opinion in Abington v. Schempp, Justice Goldberg expressed a virtually identical sentiment. ${ }^{191} \mathrm{He}$ wrote that the "fullest realization of true religious liberty requires that government ... effect no favoritism among sects or between religion and nonreligion. ..." ${ }^{192}$ The Court in Lynch v. Donnelly stated that the constitution "affirmatively mandates accommodation, not merely tolerance, of all religions, and forbids hostility toward any." 193 In Church of the Lukumi Babalu Aye, Inc. v. City of Hialeah, the Court stated that the "principle that government may not enact laws that suppress religious belief or practice is so well understood that few violations are recorded in our opinions." 194 These sentiments are shared by commentators writing on the topic. ${ }^{195}$

In light of the current state of our scientific understanding of the natural world, the answer to the question of whether public schools can teach that the theist God does not exist is not as straightforward as the Supreme Court and other commentators suggest. I argue that neither the Court nor the commentators had in mind that the existence of the theist God was an empirical question. Additionally, courts and commentators do not sufficiently distinguish between the deist God and the theist God; they also do not

189. County of Allegheny v. ACLU, Greater Pittsburgh Chapter, 492 U.S. 573, 610 (1989) (pointing out that a state can neither be too accommodating nor antagonistic towards religion).

190. Id. at 593-94 (emphasis added).

191. 374 U.S. 203, 305 (1963) (Goldberg, J., concurring).

192. $I d$.

193. 465 U.S. 668,673 (1984).

194. Church of the Lukumi Babalu Aye, Inc. v. City of Hialeah, 508 U.S. 520,523 (1993); see also United States v. Ballard, 322 U.S. 78, 87 (1944) ("With man's relations to his Maker and the obligations he may think they impose, and the manner in which an expression shall be made by him of his belief on those subjects, no interference can be permitted. . . .). But see Kiryas Joel Village School District v. Grumet, 512 U.S. 687, 717 (1994) ("The Religion Clauses prohibit the government from favoring religion, but they provide no warrant for discriminating against religion.").

195. See, e.g., Kent Greenawalt, Establishing Religious Ideas: Evolution, Creationism, and Intelligent Design, 17 Notre Dame J.L. Ethics \& Pub. PoL'y 321, 333 (2003). Although Greenawalt gives only examples of public schools being too religious, it is fair to presume that Greenawalt regards the existence of a theist God as one of the doctrines that public schools cannot teach as true or false. 
consider the use of the memist God. As such, they could not have considered the full constitutional consequences of teaching that the theist God does not exist. By revealing the underlying constitutional concerns, I show that teaching the non-existence of a theist God may successfully avoid any constitutional pitfalls.

\section{A. Establishment Clause Values and the Theist God}

There are various underlying values to the Establishment Clause. Noah Feldman argues persuasively that both rationalists and evangelists of the founding era based their arguments for the Establishment Clause on the Lockean concept of liberty of conscience. ${ }^{196}$ Locke grounded his theory on the idea that it was a sin to act against one's conscience. As such, it was believed to be outside the jurisdiction of the civil government to intervene in the relationship of an individual and his God. For, if a person was compelled to support the church against his will, his participation would effectively require him to commit the sin of hypocrisy. ${ }^{197}$ A separation between church and state was thus needed to preserve the separate jurisdictions of "God and Caesar"198 and to avoid compelling an individual to violate the tenets of her faith. By the late eighteenth century, liberty of conscience was broadly understood as a fundamental, natural right ${ }^{199}$ and it provided the rationale that unified support for the Establishment Clause. ${ }^{200}$

196. Feldman, supra note 2, at 346, 371.

197. Id. at 364 .

198. When asked whether Jews should pay taxes to Caesar, Jesus responds, "[R]ender therefore unto Caesar the things that are Caesar's; and to God the things that are God's." Matthew 22:21 (King James).

199. Feldman, supra note 2, at 374. Interestingly, Feldman also points out that liberty of conscience was not believed to extend to atheists. Such a belief system was thought to be "abominably criminal." Id. at 376 .

200. Id. at 374. While Feldman convincingly argues that the liberty of conscience concept brought the competing factions together, it does not follow that it was the principle concept underlying the Establishment Clause. The constitutional debate took place within the context of funding for state churches. Liberty of conscience brought people to conclude that individuals should not be compelled to support a church against their will. However, this was in the context of "non-preferentialist" support of religion (i.e., government could not give preference to one religion over others). By the time of the founding era however, few people advocated for a "preferentialist" support of religion. The reasons that preferentialism fell out of favor, namely divisiveness and the denial of equal protection, must also be considered one of the principle tenets underlying the Establishment Clause.

Additionally, Feldman recognizes that divisiveness and lack of equal treatment are important principles in the Establishment Clause. His dismissal of these principles however, is not entirely convincing. Feldman writes that the "main result of this concern for equal participation in government was not the Establishment Clause, but the constitution's prohibition on religious oaths or tests for service in government." Id. at $351 \mathrm{n} .26$. Given the colonists history of escaping from religious persecution in Europe, 
Teaching that the theist God does not exist would not offend this underlying principle. As Feldman points out, the constitutional debate on the Establishment Clause took place in the context of the compulsory payment of taxes to support churches. ${ }^{201}$ United around the concept that no one should be compelled to financially support religion against his will, a consensus emerged around the concept of liberty of conscience. This concern is simply not broached by teaching that the theist God does not exist.

However, there is a more subtle strand of the liberty of conscience concept that does appear to be raised by excluding the theist God. The "enlightened" deists believed that a man's mind was created free and that Government therefore could not coerce religious belief. ${ }^{202}$ To them, religious belief should spread through "its influence on reason alone." ${ }^{203}$ While it appears that excluding the theist God would interfere with the deists' view of a free and unmolested mind, there is substantial evidence to suggest that if the founders had recognized a clear conflict between science and religion, they would have sided with good science.

The Founding Fathers were children of the Enlightenment. They were nothing short of enchanted by the power of science and even believed that it illuminated political and theological matters. ${ }^{204} \mathrm{In}$ fact, in the late eighteenth century, there was a blurry distinction, if any, between scientist and statesman. ${ }^{205}$ Thomas Jefferson, James Madison, Alexander Hamilton, and Benjamin Franklin each had a profound interest in science and mathematics. ${ }^{206}$ They were suspicious of religious orthodoxy and were well aware of religion's chilling effect on free inquiry. To a large extent, this concern underlies the First Amendment as the founders sought to prevent the persecution of American Galileos. ${ }^{207}$ If disproving the theist God is the direction in which

\footnotetext{
it is unlikely that dissenters' only concern would be that they be allowed to serve in public office.

201. Feldman, supra note 2, at 351.

202. Id. at 391-92. (1779))

203. Id. at 392 (quoting Thomas Jefferson, A Bill for Establishing Religious Freedom

204. Steven Goldberg, The Constitutional Status of American Science, 1979 U. ILL. L. Rev. 1, 2 (1979) ("Veneration of science was a central tenet of eighteenth century Enlightenment thinking, for science was believed to illuminate not merely natural phenomena but political and theological matters as well."). 205. Id. at $2-3$.

206. $I d$.

207. Goldberg, supra note 204. James Madison echoes the view that the Establishment Clause is, in part, designed to promote the spread of reason and to protect against the spread of ignorance. He wrote: Experience witnesseth that eccelsiastical establishments, instead of maintaining the purity and efficacy of Religion, have had a contrary operation. During almost fifteen centuries, has the legal establishment of Christianity been on trial. What have been its fruits? More or less in all
} 
good science takes us, there is little reason to believe that the founders would object. ${ }^{208}$ On the contrary, their views on liberty of conscience are directly responsible for providing researchers the freedom to build the case for a world without the theist God. By limiting the church's role in civil affairs, the founders ensured that ideas could not be censored or suppressed merely because they conflicted with or undermined religious doctrine.

In addition to liberty of conscience, the Founding Fathers were strongly influenced by the principles of avoiding division and discrimination along religious lines. Because of the colonists' memories of religious persecution and religious wars in Europe, proponents of the Establishment Clause sought safeguards against the forming of a theocracy. ${ }^{209}$ It was believed that division along religious lines, if combined with the wielding of the levers of state power, would inevitably lead to the same kind of religious persecution and discrimination that caused the initial colonists to flee from Europe.

The lessons learned from history by the early colonists formed the basis for religion's special treatment in the First Amendment. As articulated by Justice Black in Everson v. Board of Education, the colonists had a very

places, pride and indolence in the Clergy; ignorance and servility in the laity; in both, superstition, bigotry and persecution.

Engel v. Vital, 370 U.S. 421, 432 n.14 (1962) (quoting Memorial and Remonstrance Against Religious Assessments, II Writings of Madison 183, 187).

208. John Locke, whose writings influenced many intellectuals during the founding era, argues that "one could never be obliged to abandon reason for something contrary to it 'under a Pretence that it is a Matter of Faith." Feldman, supra note 2, at 371 (citing John Locke, An Essay Concerning Human Understanding 694 (Peter H. Nidditch ed., Oxford Univ. Press 1979) (1690)). However, in the late eighteenth century, it was widely believed that the protections of liberty of conscience did not extend to atheists. See Feldman, supra note 2, at 376 ("Denial of God evidently was not compatible with the idea of a conscience liberated by Christ's sacrifice."). Today however, atheists are clearly protected under the religion clauses. See Torcaso v. Watkins, 367 U.S. 488 (1961).

209. 2 Kent Greenawalt, Religion and the Constitution, Volume 2: Establishment and FAIRNESS 11 (2008)

[T] he avoidance of conflict along religious lines is an important objective. Inevitably, some tensions will exist between adherents of different religions who believe each other to be fundamentally misguided about ultimate truth. But the tensions are bound to increase if those adherents see themselves in a struggle for state support—-financial and other-and for the levers of political power.

Van Orden v. Perry, 545 U.S. 677, 698 (2005) (Breyer, J., concurring) ("They [the Religion Clauses] seek to avoid that divisiveness based upon religion that promotes social conflict, sapping the strength of government and religion alike."); Steven H. Shiffrin, The Pluralistic Foundations of the Religion Clauses, 90 Cornell L. Rev. 9 , 40 (2004); but see Steven D. Smith, Book Review: Discourse in the Dusk: The Twilight of Religious Freedom, 122 HaRV. L. REV. 1869, 1895-96 (2009) and Michael W. McConnell, Political and Religious Disestablishment, 1986 BYU L. Rev. 405, 413 (1986) (arguing that division along religious lines has never been as severe as it has been with "the Vietnam War, racial segregation, the Red Scare, unionization, or slavery."). 
palpable understanding of the link between religious rule and the resulting persecution, civil strife, and warfare, all based on distinctly religious grounds. ${ }^{210}$ While various other economic, social, and territorial conflicts could produce the same set of maladies, the belief was that when they were combined with religious zealotry, the incidents were more frequent and the consequences were more intense. ${ }^{211}$

I argue that the belief in a theist God is intimately tied to the Establishment Clause. The theist God issues categorical commandments that must not be questioned. The theist God is also the entity that holds adherents accountable so that if they disregard a command, they run the risk of being either temporally or eternally punished. Because of the theist God's power to intervene either in the natural or supernatural world to mete out punishment, the psychological trauma associated with violating a moral principle is likely to be greatest in the minds of the religious. ${ }^{212}$ Invariably, the commands of different religious groups will eventually conflict and their categorical adherence will make it difficult to compromise. ${ }^{213}$ When one religious group is armed with the power of government, the consequences of persecution, civil strife, and warfare seem almost inevitable. ${ }^{214}$ It is this outcome that the Establishment Clause is in large part designed to prevent.

By eliminating the theist God, the underlying goal of preventing hostility and subordination is thereby furthered. ${ }^{215}$ While civil division and the denial

210. Everson v. Bd. of Educ., 330 U.S. 1, 8-13 (1947); Rodney J. Blackman, Showing the Fly The Way Out of the Fly-Bottle: Making Sense of the First Amendment Religion Clauses, 42 U. KAN. L. REv. 285, 306-08 (1994) ("Religious differences often have the potential of producing highly emotive fratricidal confrontations, communal maelstroms and state anarchy. Also, religious fanaticism often correlates highly with ignorance of and indifference toward secular knowledge and economic backwardness.").

211. $I d$.

212. Dean Jesse Choper argues that an important distinction between religious and non-religious objectors to military service is that "the degree of internal trauma" will be greater for the religions persons "who have put their souls in jeopardy for eternity." Although he concedes it would be difficult to empirically test it, intuition and experience tell us that the "psychic turmoil" will be greater for the religious than the non-religious. Jesse H. Choper, Defining "Religion" in the First Amendment, 1982 U. ILL. L. REv. 579, 598-99 (1982).

213. Blackman, supra note 210 , at 306 ("Religious differences often have the potential of producing highly emotive fratricidal confrontations, communal maelstroms and state anarchy.").

214. Everson v. Bd. of Educ., 330 U.S. 1, 12 (1947) (discussing James Madison's Memorial and Remonstrance). Id. at 9 ("With the power of government supporting them, at various times and places, Catholics had persecuted Protestants, Protestants had persecuted Catholics, Protestant sects had persecuted other Protestant sects, Catholics of one shade of belief had persecuted Catholics of another shade of belief, and all of these had from time to time persecuted Jews.").

215. It is, of course, possible that the government's own act of eliminating the theist God would have the effect of causing an uproar and creating division and hostility. However, it should be noted that the uproar and hostility should be similar to that caused by the teaching of evolution in public schools. While 
of equal protection will invariably continue on other grounds, removing the theistic influence may suppress the religious fervor that has fueled atrocities in the past. ${ }^{216}$ This underlying Establishment Clause value of preventing division and subordination, or at least lessening its intensity, is thus promoted by eliminating the theist God. ${ }^{217}$

Finally, it appears that the most intense opposition of government aid to religion came from the most religious groups. ${ }^{218}$ It was believed that it was important to keep the two separate so as to prevent the corruption of religion by government. ${ }^{219}$ Since the constitutional debate centered on the federal and state governments' abilities to financially support churches, eliminating the theist God would not affect this underlying principle. It might be suggested however, that government is nonetheless infringing on religion, if not corrupting it, by meddling in a matter that properly concerns the church. For example, it could be argued that the relationship an individual has with his or her God is a matter that is beyond the jurisdiction of "Caesar." ${ }^{220}$ But as stated previously, so long as religions make empirical claims, there will necessarily be an overlap between secular and religious views. ${ }^{221}$ If religious viewpoints are allowed precedence over the secular, science-based views, they may conflict with the founders' and the First Amendment's underlying interest in promoting free inquiry. ${ }^{222}$

it may be politically unpopular to adopt such a policy, it need not be a constitutional violation. Courts have never found that teaching good science violates the constitution.

216. Cf. Blackman, supra note $210,306-07$.

217. Note that the memist God could play a similarly divisive role as the theist God. As with theism, adherents can believe that the memist God issues categorical commandments and that It will hold them ultimately accountable. Whereas in the theist context, it can be stated that God does not issue categorical commands (because He does not exist), the same cannot be said in the memist context. For if an individual believes that the memist God makes any given command, that is sufficient proof of its truth. Supra text accompanying notes 58-67. As for the ability of the memist God to hold an individual ultimately accountable, it can be treated exactly as the theist God. Since the memist God resides in His adherents' brains, it is illogical to conclude that the same memist God will "act" after the brain ceases to function. But regardless, the memist God can hold adherents accountable for their transgressions throughout their lives; this is exactly the same as the psychological pain adherents may feel when committing a sin. Therefore, memists would have an internally-consistent cause for living life according to a strict moral code. However, the idea that God will punish you independent of your actions or the actions of others would be eliminated.

218. McConnell, supra note 209, at 413.

219. Shiffrin, supra note 209, at 42-47; Zorach v. Clauson 343 U.S. 306, 320 (1952) (Black, J., dissenting) ("State help to religion injects political and party prejudices into a holy field.").

220. See supra note 201. This is the precise argument made by Justice Douglas in Ballard, where he states that "[m]an's relation to his God was made no concern of the state." United States v. Ballard, 322 U.S. 78, 87 (1944).

221. See supra Part I.A.

222. See supra text accompanying notes $202-08$. 
Although they were not privy to an evolutionary perspective, each of Benjamin Franklin, George Washington, John Adams, Thomas Jefferson, James Madison, James Monroe, and Thomas Paine had deist inclinations. ${ }^{223}$ If they had the benefit of understanding evolution, the veneration they had for science leads me to believe that they would have followed wherever good science led them. Therefore, it should not be surprising that eliminating the theist God who violates the laws of physics would not conflict with the principles that underlie the Establishment Clause.

\section{B. Free Exercise Clause Values and the Theist God}

Justice Scalia's opinion in Employment Division Dept. of Human Res. v. Smith lays out the values underlying the Free Exercise clause. Justice Scalia writes:

[t]he free exercise of religion means, first and foremost, the right to believe and profess whatever religious doctrine one desires. Thus, the First Amendment obviously excludes all governmental regulation of beliefs as such. The government may not compel affirmation of religious belief, punish the expression of religious doctrines it believes to be false, impose special disabilities on the basis of religious views or religious status, or lend its power to one or the other side in controversies over religious authority or dogma. ${ }^{224}$

Although the Smith decision has proved to be controversial, this aspect of the opinion, as it relates only to religious beliefs, is straightforward and uncomplicated. If the Free Exercise clause means anything, it means that a person should be free to believe what he or she wishes.

Returning to the hypothetical I posed, supra, where a teacher gives a student a lower grade for claiming that the Earth is 6,000 years old, it would appear that every aspect of the Free Exercise Clause, as articulated in Smith, has been violated. The government would be regulating beliefs and punishing students who disagreed. Under the reasoning of Sherbert v. Verner ${ }^{225}$ and Thomas v. Review Board, ${ }^{226}$ a Free Exercise violation is based on the government requiring that parties choose between "perform[ing] an act which

223. David L. Holmes, The Faiths of the Founding Fathers 50-51 (2006).

224. Employment Div., Dept. of Human Res. v. Smith, 494 U.S. 872, 877 (1989) (internal citations omitted).

225. Sherbert v. Verner, 374 U.S. 398 (1963) (denial of unemployment benefits for religiously-based refusal to work on Saturday deemed unconstitutional).

226. Thomas v. Review Bd., 450 U.S. 707 (1981) (denial of unemployment benefits for religiouslybased refusal to work on military tanks deemed unconstitutional). 
violated [their] religious convictions or forego[ing] benefits. ${ }^{227}$ In this fact pattern, government would not only be exposing students to different beliefs, it would be actively compelling them to accept them as true, ${ }^{228}$ students would have to choose between violating their religious beliefs or receiving a lower grade. The Free Exercise Clause would thus appear to be violated. However, since a science teacher must be able to teach basic facts such as the age of the Earth, the language in Smith and the rationale in Sherbert and Thomas cannot be used as a guide for resolving conflicts between secularism and religion on empirical matters. Similarly, these cases do not help resolve the question of whether the school board can adopt the hypothetical textbooks.

As mentioned above, so long as there is sufficient scientifically-sound evidence, the principle from Abington and Crowley would allow schools to teach that a theist God does not exist. The logical extension of this conclusion tells us that schools should also be able to teach that the theist God does not command you to hold certain beliefs or to perform certain acts. If the theist God does not exist, certainly He does not require that you hold certain beliefs. In this way, even the normative claims made by religion would appear to be subject to being exposed as false. If this were the case, it would strike at the heart of the Free Exercise clause and would effectively obliterate its significance.

Teaching that the theist God does not exist however, does not reach so far. There are two independent reasons why religion's non-empirical claims must remain intact. First, if the memist view of God is adopted, there is no reason why religion's normative claims would be affected. Since memism makes the same normative claims as theism, religion's normative claims may never be disconfirmed. These normative claims may be contradicted and undermined, as will inevitably occur in a pluralistic society, but they can never be declared to be false. ${ }^{229}$ For example, conservative religious views toward sex and contraception are often undermined in high school sex education classes. Because there is a secular purpose of promoting public health and because a wide range of viewpoints may be discussed, there is no such First

227. See Mozert v. Hawkins County Bd. of Educ., 827 F.2d 1058, 1065 (6th Cir. 1987) (finding that the outcomes in both Sherbert and Thomas were based on the government compelling religious adherents to adopt the orthodox view).

228. See Sch. Dist. of Abington Twp., Pa. v. Schempp, 374 U.S. 203, 223 (1963) (“" [I]t is necessary in a free exercise case for one to show the coercive effect of the enactment as it operates against him in the practice of his religion."); Engel v. Vital, 370 U.S. at 430 (stating that a Free Exercise violation "depend[s] upon [a] showing of direct governmental compulsion").

229. See supra text accompanying notes $27-28$. 
Amendment violation. ${ }^{230}$ However, if it were stated that a religion's views on sex were outright wrong, the government would clearly violate the first amendment. Similarly, if the government claimed that God did not command such a view towards sex, because this would conflict with the memist view of God, it would violate the core prohibition in Smith.

Even if the memist view is not adopted, teaching that the theist God does not exist would not disturb religion's normative claims. The reason for this is that there is an important distinction between the source of one's beliefs and the actual substance of those same beliefs. In the example of the high school exam, since the age of Earth is an empirical claim, the teacher can implicitly make two separate claims to the religious student: first, your source of authority is wrong (because the theist God does not exist) and second, your conclusion is wrong (because science disconfirms it). However, with respect to normative claims made by religion, the teacher would be able to state that the source of the belief is wrong (because the theist God does not exist) but be unable to state, one way or the other, whether the underlying belief is either true, false, valuable or not (because science does not speak to normative issues). Although the student would need to find a new source of authority, her underlying substantive belief would remain undisturbed. Not only does this distinction help avoid the potential Free Exercise problem but, counter intuitively, it may open the door for religious groups to have a greater say on public policy matters.

The distinction between the source of a normative belief and the substance of that same belief is key. The disconfirmation of the source of the religious belief follows naturally from the discussion throughout this article. By setting aside the theist source of the belief however, its standing relative to secular beliefs is bolstered. This point is commonly misunderstood. It is often believed that if a faith-based religious belief loses its divine source, it becomes baseless and thus diminishes in stature relative to reason-based, secular beliefs. This belief is flatly wrong.

For example, how do you distinguish the religious belief that one should honor their mother and father from the secular belief that one should do the same thing? ${ }^{231}$ There is no inherent property of either belief that can be used to distinguish them because they are, in fact, identical. If we look beyond the

230. Decided on Establishment Clause grounds, see Cornwell v. State Board of Ed., 314 F. Supp. 340 (D. Md. 1969), aff'd, 428 F.2d 471 (4th Cir. 1970); Citizens for Parental Rights v. San Mateo County Board of Educ., 124 Cal. Rptr. 68 (Cal. Ct. App. 1975); Smith v. Ricci, 446 A.2d 501 (N.J. 1982).

231. Although this is not an exclusively religious belief, it is codified in the Christian tradition by the biblical passage, "Honour thy father and thy mother. ..." Exodus 20:12. 
substance of the belief and instead focus on the source or reason for it, we still do not have a sensible way to distinguish between them. The secular belief will, at its core, be as devoid of a reason as the belief based on religious faith!

The secular belief that one should honor their parents might have a genetic basis, meaning that it played an instrumental purpose that somehow conferred a genetic advantage in our evolutionary past. For example, Richard Dawkins argues that evolution might select for children who instinctively obey their parents. ${ }^{232} \mathrm{He}$ argues that believing whatever your parents tell you "is a generally valuable rule for a child." ${ }^{233}$ As Jared Diamond notes, it seems that parents played an important role in ancient human societies long after childrearing was complete. Perhaps they helped in daily affairs such as watching over grandchildren, or perhaps they assisted in infrequent yet tremendously important ways such as remembering where the villagers safely hid two generations ago when the last great storm came their way. ${ }^{234}$

The key point here is that if genetic evolution selected for this trait, then the foundation of the impulse to honor your parents is encoded in the genes. ${ }^{235}$ The ultimate basis for this belief would therefore be instinctive and not based on reason. So, if a secularist were pushed to provide the ultimate reason for his belief that parents should be honored, he will eventually have to concede that reason runs out. ${ }^{236}$ Every secular belief, whether based on philosophy, economics, sociology, politics, or otherwise, must eventually make a value

232. Dawkins, God Delusion, supra note 11, at 174.

233. Id.

234. Jared Diamond, Collapse: How Societies Choose to Fail or Succeed 12 (2005) and Judy Lin, Honor or abandon: Societies' treatment of elderly intrigues scholar, UCLA TodAY, Jan. 7, 2010, available at $\mathrm{http} / / / \mathrm{www}$. today.ucla.edu/portal/ut/jared-diamond-on-aging-150571.aspx.

235. The information to instinctively obey your parents need not be encoded in your genes. Another interesting explanation, if not justification, for the belief that parents should be honored is that parents have duped their children because of the parents' selfish motives. For instance, parents might self-servingly inculcate their children with this belief so that they may be cared for in their old age and beyond. As Steven Pinker humorously speculates, "[a]ncestor worship must be an appealing idea to people who are about to become ancestors. As one's days dwindle, life begins to shift from an iterative prisoner's dilemma, in which defection can be punished and cooperation rewarded, to a one-shot prisoner's dilemma, in which enforcement is impossible. If you can convince your children that your soul will live on and watch over their affairs, they are less emboldened to defect while you are alive. Steven Pinker, How the Mind Works 555 (1997). Regardless, your parents' selfish motives are hardly a good reason for your believing that they should be honored.

236. The fact that it is encoded in our genes does not give it any positive normative weight. Many impulses should actively be acted against. See supra text accompanying notes 141-42. 
judgment. ${ }^{237}$ This leap of faith places all secular convictions on an initial plane that is equal to religious ones.

The Free Exercise Clause ensures that each individual is free to believe whatever she wishes. Although the underlying basis of a belief may be questioned (if it is based on the existence of a theist God), so long as the substantive belief is not disturbed, the core value of the Free Exercise Clause is preserved. Eliminating the theist God does not affect an individual's right to hold the beliefs of his choice. As for the bases of one's beliefs, eliminating theism would certainly allow public school teachers to state that the theist God does not make such a command. But in doing so, the underlying substance of the religious belief is not in the slightest bit diminished. Rather, a scientific understanding of the natural world shows us that this will place religious beliefs alongside secular ones. Of course, the underlying religious beliefs would need to be defended on rational, reason-based grounds, but religious groups already do so: for example, abortion and stem cell research are opposed on the grounds that they are akin to murder and homosexuality is opposed on the grounds that it threatens the tradition of heterosexual marriage. To religious groups, the need to justify these beliefs on reason-based grounds does not appear to diminish the significance they assign to them.

Therefore, I am led to conclude that government would not violate the rights of religious groups if it adopted the position that the theist God does not exist. As long as all that is being disconfirmed is the aspect of God that intervenes in the natural world and violates the laws of physics, none of the values underlying either of the religion clauses are offended.

\section{Application of Framework}

Beyond the hypothetical textbooks case, it is important to give a few examples to explain how the framework I lay out would address real cases that may arise. A high school teacher may tell students that the theist God did not create man out of sand, that He did not impregnate a virgin, that He did not help a man walk on water, that He did not cause the January 2010 earthquake in Haiti, and that he did not cause it to rain last week. Because each would cause the theist God to violate the laws of physics, we can state with certainty that He was not the cause. ${ }^{238}$

237. Cf. Choper, supra note 212, at 603 ("at the level of the final decision, even the most frankly utilitarian goals depend ultimately on values - such as good or evil, or even the desirability of human survival — that represent normative preferences rather than rationally compelled choices.").

238. God may in fact be the cause of the earthquake and the weather pattern if God is defined in 
However, a school teacher may not state that God did not dictate a holy book, that He did not inspire an individual to create a work of art, that He does not respond to prayers or provide guidance, and that He does not issue moral commandments. Because each of these acts takes place within a person's mind and does not require a violation of the laws of physics, science does not disconfirm them. ${ }^{239}$ As such, it is a matter of fact that holy books and great works of art are divinely inspired, so long as their creators felt as though they were being directed by God. Just the same, it is a matter of fact that God "speaks" to and helps guide individuals, so long as God is understood as a concept that resides in the mind. As long as God is not thought to violate the laws of physics, a public school teacher cannot disparage Him without violating the constitution.

In United States v. Ballard, the Supreme Court first articulated its virtually sacrosanct prohibition against determining the "truth or falsity" of religious beliefs. ${ }^{240}$ In Ballard, the United States charged Mr. Ballard and others with conspiracy to defraud after they solicited funds under the pretense that Mr. Ballard had achieved supernatural powers. Under the teachings of the "I Am" movement, Mr. Ballard alleged, for example, to have "in fact cured ... hundreds of persons afflicted with diseases and ailments" ${ }^{\prime 241}$ and to have written a number of religiously inspired "letters" in Mount Shasta, California. ${ }^{242}$ The Court was then left to decide whether his "extremely improbable" comments could be evaluated for their truth or falsity.

In upholding Mr. Ballard's right to "freedom of thought," the Court stated that " $[\mathrm{m}]$ en may believe what they cannot prove ... [but] they may not be put to the proof of their religious doctrines and beliefs." 243 Thus, the Court held that "questions concerning the truth or falsity of . . . religious beliefs or doctrine[]" are within a "forbidden domain" that government must not enter. ${ }^{244}$ The only matter that courts could legitimately inquire into was whether the religious beliefs were sincerely held. If Mr. Ballard sincerely believed the

\footnotetext{
pantheistic terms. However, for purposes of this article, pantheism is akin to deism or atheism. What is important is to isolate the one aspect of the theist God, namely the ability to violate the laws of physics, to which science speaks. See supra Part II.A.

239. However, to the extent that science does speak to them, science confirms them. See supra text accompanying notes 63-66.

240. United States v. Ballard, 322 U.S. 78, at 87-88 (1944).

241. Id. at 80 .

242. Ballard v. United States, 138 F.2d 540, 544 n.10 (9th Cir. 1943), rev'd, 329 U.S. 187 (1946).

243. Ballard, 322 U.S. at 86 .

244. Id. at $87-88$.
} 
representation he made, then he would not be guilty of fraud, regardless of how extravagant or implausible his claims might have been.

The decision in Ballard was strongly motivated by the idea that if a court could determine whether the defendant's beliefs were true or false, that "the same can be done with the religious beliefs of any sect." ${ }^{245}$ Although the Court was highly suspicious of the underlying truth of Mr. Ballard's claims, it felt that it would be effectively impossible to limit the scope of a court's inquiry. If the government engaged in such determinations, according to the Court, "little indeed would be left of religious freedom."246 In fact, Justice Roberts' dissenting opinion goes even further and would disallow even the inquiry into the sincerity of the beliefs. According to Justice Roberts, "[p]rosecutions of this character could easily degenerate into religious persecution."247

However, the framework that I set out provides precisely the kind of limiting principle that both the Court and Justice Roberts were unable to articulate. As Justice Stone alluded to in his dissenting opinion, the question of whether Mr. Ballard was ever in California or whether he did in fact heal the sick are matters that courts are well equipped to determine. ${ }^{248}$ The fact that these claims were religious in nature does not make them any more difficult for courts to decide. The Court therefore could have articulated a principle by simply limiting the inquiry to Mr. Ballard's empirical claims that would have required him to violate the laws of nature. If the government could produce sufficient evidence to prove that the empirical claims did not occur, such as the fact that Mr. Ballard was not in California because he was somewhere else, then there should be no problem in declaring that the claims are false. As long as the inquiry is limited to empirical claims, the Court's slippery slope argument would not materialize and religious freedom would not be infringed. However, because the Court saw no way to effectively limit the principle that the truth or verity of religious beliefs could not be addressed, it issued a rule that was broader than necessary. ${ }^{249}$

\section{Id. at 87.}

246. $I d$.

247. Id. at 95 (Jackson, J., dissenting).

248. See Jared A. Goldstein, Is There a "Religious Question" Doctrine? Judicial Authority to Examine Religious Practices and Beliefs, 54 CATH. U. L. REV. 497, 501 (2005) (arguing that courts are competent to resolve positive question but that they should refrain from resolving issues that turn on normative religious beliefs).

249. The decision to not determine the truth or falsity of religious claims did not affect the outcome in Ballard. Because both the majority and Justice Stone believed that the defendants made the representations knowing that they were false, the Ballards' convictions would be upheld under either opinion. 


\section{Can Government Be Too Secular?}

The constitution requires that all government policies be justified on secular grounds. ${ }^{250}$ If a secular purpose exists, so long as the "principal or primary" effect is one that neither advances nor inhibits religion, government is not limited in how secular it can be. ${ }^{251}$ With respect to all non-empirical matters, the fact that a secular purpose is pursued or that a secular effect is achieved (1) does not rule out the possibility that a religious purpose or effect is also advanced, ${ }^{252}$ or (2) does not necessarily mean that the government policy is inhibiting religion. ${ }^{253}$ For example, pursuing the secular purpose of punishing theft is likely to also advance some religious beliefs, and it also does not necessarily inhibit religion. Secularism and religion can coexist and therefore the constitution is not offended.

Regarding empirical claims however, it is much more likely that in pursuing a secular purpose or achieving a secular effect, the government action will have the effect of inhibiting religion. Since empirical claims lend themselves to a determination that they either accurately match observations or not, it is possible that the secular and religious views will directly conflict. Thus, if the government pursues a policy of teaching the science-based secular view, the result may be interpreted as being non-neutral and anti-religious.

For example, assume that the purpose of adopting the hypothetical textbooks is to teach the leading scientific theories of the day and that the means of achieving it is by teaching that the theist God, with the power to violate the laws of physics, does not exist. ${ }^{254}$ The government policy may be

Jared Goldstein is similarly critical of the Court's decision in Ballard. Goldstein argues that "notwithstanding Ballard's rule against judging the truth or falsity of religious claims, courts effectively may issue governmental declarations that certain religious beliefs are false." Id. at 532-33.

250. Lemon v. Kurtzman, 403 U.S. 602, 612-13 (1971) ("First, the statute must have a secular legislative purpose; second, its principal or primary effect must be one that neither advances nor inhibits religion, finally, the statute must not foster an excessive government entanglement with religion.") (internal citations and quotations omitted).

251. $I d$.

252. Since the justification of any policy is limited only by the creativity of the mind, virtually any religious purpose can be supported by a secular purpose. So long as the secular purpose is furthered, the fact that a religious purpose is also furthered is immaterial. Smith, supra note 20.

253. Most laws will be neutral towards religion. Traffic laws, for instance, while furthering the secular purpose of traffic safety, do not necessarily inhibit religion.

254. Even if the means are considered religious, it should not affect the outcome. The Supreme Court has upheld government action where the means of achieving a secular purpose were distinctly religious. See Lynch v. Donnelly, 465 U.S. 668 (1984) (finding that the display of nativity scene on public grounds, within a larger holiday display, did not violate the Establishment Clause). 
defended on the grounds that the effect is that students are taught a view of the natural world that is based on good science. If a court adopts this interpretation, no constitutional violation will exist. However, the policy may be attacked on the ground that while one of the effects is the secular one just mentioned, the "principal and primary" effect is one that is hostile to religion. When science and religion disagree on empirical matters, it may be argued that the secular effect is inherently anti-religious. Courts would then be left to determine whether the "principal and primary" effect of the policy is one that inhibits religion. As discussed supra ${ }^{255}$ however, it would be antithetical to the values of the framers to strike down the policy on the sole ground that it contradicts a religious interpretation of an empirical fact. As with evolution, the fact that science's conclusions contradict deeply-held religious beliefs should not be the basis of a constitutional bar to teaching it in public schools.

But even if a persuasive case against the adoption of the hypothetical textbooks cannot be made on the basis of the values protected by the Establishment and Free Exercise Clauses, a strong argument may nonetheless be made on secular grounds. It may be argued that using such textbooks would cause a level of psychological turmoil to religious students that would trump whatever benefits may be achieved by the policy. ${ }^{256}$ Or perhaps it can be argued that government should refrain from adopting policies that will unnecessarily offend its citizens, particularly ones that will affect impressionable and not fully mature high school students. ${ }^{257}$

While these arguments may be quite persuasive, they are based on political considerations and not on the protection of a constitutional principle. If constituents are deeply troubled by the adoption of such a policy, they would certainly be able to seek recourse through the political process. Constituents can seek both a reversal of the textbook policy and perhaps a preemptive policy that forbids the teaching of science's effect on the existence

255. See supra Part III.A.

256. Dean Jesse Choper argues that an important distinction between religious and non-religious objectors to military service is that "the degree of internal trauma" will be greater for the religions persons "who have put their souls in jeopardy for eternity." Although he concedes it would be difficult to empirically test it, intuition and experience tell us that the "psychic turmoil" will be greater for the religious than the non-religious. Choper, supra note 212, at 598-99.

257. Justice Black makes this precise argument in his concurrence in Epperson. Epperson v. Arkansas, 393 U.S. 97, 113 (1968) (Black, J., concurring). 
of the theist God. ${ }^{258}$ But convincing a court to declare the policies unconstitutional is a task that I believe is unlikely.

In sum, while the elimination of the theist God may at first glance seem like a bold, intrepid step, after this analysis, it appears to be a more modest one. Even if the theist God is eliminated, the deist and memist gods still remain. Deism allows for individuals to search for answers to the transcendental and ultimate questions of life. And memism allows for people to live according to any particular moral code and to worship God as they see fit. The core features that give religion its special significance in people's lives remain entirely intact. I am led to conclude that there is no constitutional limit to how secular government can be.

\section{CONCLUSiON}

Religion has come under intense scrutiny in recent years. Because of its tendency to issue categorical commands and to insulate itself from evidence and reason, Brian Leiter concludes that there is no principled basis for tolerating religion. ${ }^{259}$ Sam Harris is similarly critical in decrying religious groups for ignoring the standards of evidence that we all, even fundamentalists, apply in just about every aspect of our lives. ${ }^{260}$ Yet, when it comes to evaluating religious claims, people seem to "require no evidence whatsoever."261

Most commentators readily acknowledge that religion has often been a source of good. It is widely accepted that religiously-motivated groups played important roles in causes such as eradicating slavery and resisting Hitler. Religions often create a sense of community, they inculcate good values (most of the time), and they give adherents purpose and direction in their lives. Also, not only do religious people report higher levels of satisfaction with their lives but individuals generally report a higher level of happiness if they are

258. However, this might not work either. If a local school board seeks to either change the policy or to preemptively adopt a policy that such matters should not be taught, it would face a challenge similar to the one in Epperson. There, the Court determined that the policy of not teaching evolution was religiously motivated even though Justice Black argued that a secular purpose might exist. See id. If a court were asked to decide the constitutionality of a policy against adopting such textbooks, it may similarly decide that the policy is religiously motivated. See id. at 112.

259. Brian Leiter, Why Tolerate Religion, Const. Comment., Winter 2008, at 1, 19.

260. HARRIS, supra note 11, at 19 (discussing the great value that we all place on evidence and reason, while lamenting the readiness with which religious individuals set evidence and reason aside when they evaluate religious claims).

261. $I d$. 
surrounded by religious people. ${ }^{262}$ Whenever religion is criticized, none of these important contributions should be discounted.

The problem with religion however, is that when it makes an empirical claim, it is effectively disregarding science. Science is a process of acquiring knowledge that, if carefully employed, gives us confidence in the reliability of our conclusions. ${ }^{263}$ This allows us to better predict the future and to prepare for it. On the contrary, religion does not so much as pretend to provide a basis that can be evaluated for reliability and accuracy. ${ }^{264}$ Presumably, we are left with the conclusory and often conversation-stopping statement that these claims, particularly, empirical claims should be believed as a matter of faith simply because the theist God commands. ${ }^{265}$ While a deep, unflinching faith is sometimes the aspect of religion that is most admirable, whenever an empirical question is concerned, accuracy should be our ultimate goal. This is a principle that our legal system already adopts ${ }^{266}$ and that I believe should

262. Arthur Brooks, Gross National Happiness 44 (2008); Andrew E. Clark \& Orsolya Lelkes, Let Us Pray: Religious Interaction in Life Satisfaction 1 (Paris Sch. of Econ., Working Paper No. 2009-01, 2009), available at http://www.pse.ens.fr/document/wp200901.pdf; but see Christopher Lewis \& Sharon Cruise, Religion and Happiness: Consensus, Contradictions, Comments, and Concerns, Mental Health, RELIGION \& CUlTURE, June 2006, at 213 (analyzing studies conducted in Europe and concluding that there is no definite relationship between religiosity and happiness).

263. To illustrate why this point is so important, we must have a firm understanding of what science is. Science is a process of acquiring knowledge that seeks to provide accurate models of the natural world. Science, as such, concerns itself only with empirical matters and these matters must be amenable to confirmation or disconfirmation. But see GREENE, supra note 72, at 384-85 (positing that there may be a limit to what we can test). For instance, through observation or experimentation, a given hypothesis is tested to determine its accuracy. Once a conclusion is reached, it is important that that it be broadly publicized, that the experiment be reproducible, that double-blind experiments be conducted, that there be an incentive for researchers to disconfirm the original conclusion, and that other researchers have academic freedom to publicize their own confirming or disconfirming conclusions. This process is cumulatively referred to as the scientific method and the enterprise that employs these methods and their results is called science. Stenger, supra note 11, at 23-25; see generally Kitzmiller v. Dover Area Sch. Dist., 400 F. Supp. 2d 707 (M.D. Pa. 2005); HARRIs, supra note 11.

If this process is employed and a conclusion is consistently confirmed, then we are justified in assuming that the conclusion is accurate. In this way, new findings are continually added to what has already been sufficiently confirmed so that it expands our existing body of knowledge. Science thereafter incorporates these new conclusions so that evermore sophisticated, complex, and accurate models of the natural world can be created. The result of this process is a greater understanding of how the world functions so that we, as humans, are in a better position to predict the future and to prepare for it.

264. HARRIS, supra note 11, at 23 ("[E]very religion preaches the truth of propositions for which no evidence is even conceivable.") (emphasis original).

265. This intransigence, even on empirical matters, makes compromise remarkably difficult for religious groups. As a result, the de facto exclusion of explicitly religious arguments from contemporary public policy debates appears to be well-warranted.

266. Daubert v. Merrell Dow Pharms., Inc., 509 U.S. 579 (1993) (stating that in order for expert testimony to be admissible it must be scientific and grounded in accepted knowledge). 
not be suspended whenever religions make empirical claims. The result may be that religion will sometimes be contradicted but since the deist and memist gods would remain, the effect would not be as great as some may initially suspect.

Along these lines, history has shown that religion has possessed a keen ability to adapt to changing circumstances. Religious groups have widely accepted secular beliefs (i.e. empirical claims) that were once thought to be heretical. Beliefs such as the Earth revolving around the sun, the Big Bang, and evolution have been effectively incorporated into various religious beliefs. As each conflict has been resolved, religions avoided a wholesale rejection of their doctrines by casting the previous conflict as merely a peripheral one. For instance, when the Catholic Church came to accept the heliocentric view, the error did not strike at the core of Catholic belief. The Earth-centered view could be discarded and the rest of Catholicism could continue undisturbed.

Can religion do the same with the non-existence of the theist God? Perhaps it can be argued that this issue is categorically different than the previous conflicts. Whereas the previous conflicts touched upon peripheral religious claims, the existence of the theist God reaches the very core of what it means to be religious. I strongly doubt this will be the case. Although I do expect that the political opposition to eliminating the theist God will be as strong as the religious groups' opposition to heliocentrism and evolution, religion will find a way to adapt.

Every human society ever studied has had some form of religious belief. This strongly implies that the impulse towards religiosity runs deep in our composition ${ }^{267}$ Religion is much more than the belief in a theist God and in fact, many religions have long thrived without such a belief. ${ }^{268}$ That religion depends on the belief in a theist God is plainly false. ${ }^{269}$ Instead, the core of religion, if in fact there is a core, is a set of shared beliefs, values, practices, rituals, and symbols that bring people together to form a community. Additionally, religion provides a framework for helping individuals answer life's most profound questions and find purpose. While some people may

267. BOYER, supra note 176.

268. For example, the non-theistic religions of Buddhism, Taoism, Ethical Culture and Secular Humanism. See Torcaso v. Watkins, 367 U.S. 488, 495 (1961).

269. It is certainly true that many groups have creeds that place the theist god as the centerpiece of their religious beliefs. However, examples such as Buddhism, Taoism, Ethical Culture, and Secular Humanism show that religion itself is not dependent on a theist God. See id.

It was believed that modernity would invariably usher in a wave of secularism. This idea however never came to pass. See Christian Smith, The Secular Revolution: Power, Interests, and Conflict in the Secularization of American Public Life 6 (2003). 
believe that the theist God is the linchpin that holds this all together, many others will invariably conclude that the other aspects of religion are nonetheless worth preserving.

If the non-existence of the theist God comes to form part of a basic public school education, it will not spell doom for religion. ${ }^{270}$ Religion is, and has always been, a remarkably successful meme. ${ }^{271}$ It has evolved to fit the needs of the times and has adapted to the ever changing zeitgeist. In an open marketplace, religion will flourish so long as it meets the needs of its consumers. With secularism on the rise in America, I suspect that the religious groups that will thrive are the ones that are best able to provide the soughtafter sense of community and purpose without requiring its constituents to believe empirical claims that contradict good science.

270. Although it might perhaps slowly eradicate religious fundamentalism.

271. A meme is a unit of cultural information in the same way that a gene is a unit of genetic information. Through the process of Darwinian evolution, memes mix, blend and re-combine with other memes to grow in complexity. The most successful memes are simply the ones that are able to make the most copies of themselves. By this account, the religion "memeplex" has been a remarkably successful meme. See Blackmore, supra note 146; Dennett, Breaking the Spell, supra note 11, at 341 (Appendix A). 